University of Chicago Law School

Chicago Unbound

Journal Articles

Faculty Scholarship

1980

\title{
The Weber Case: The Judicial Abrogation of the Antidiscrimination Standard in Employment
}

Bernard D. Meltzer

Follow this and additional works at: https://chicagounbound.uchicago.edu/journal_articles

Part of the Law Commons

\section{Recommended Citation}

Bernard D. Meltzer, "The Weber Case: The Judicial Abrogation of the Antidiscrimination Standard in Employment," 47 University of Chicago Law Review 423 (1980).

This Article is brought to you for free and open access by the Faculty Scholarship at Chicago Unbound. It has been accepted for inclusion in Journal Articles by an authorized administrator of Chicago Unbound. For more information, please contact unbound@law.uchicago.edu. 


\title{
The \\ University \\ of Chicago \\ Law Review
}

VOLUME 47 NUMBER 3 SPRING 1980

\section{The Weber Case: The Judicial Abrogation of the Antidiscrimination Standard in Employment}

\author{
Bernard D. Meltzer $\dagger$
}

In United Steelworkers v. Weber, ${ }^{1}$ the Supreme Court, dividing five to two, ruled that Title VII of the Civil Rights Act of $1964^{2}$ permits employers under certain circumstances to grant black workers employment preferences. This division within the Court is a reminder that Weber is a case of great significance. In giving a new answer to the question of how "equality" was defined by Congress in the 1964 Civil Rights Act, the Court's decision cuts deeply into the values underlying that legislation. It also underscores old questions as to the institutional role and competency of the Court-how its perceptions and values should be meshed with those reflected in the language and history of a statute. Although Weber's reach and implications are, as we shall see, obscure, its potential radiations are far reaching, extending to virtually all em-

$\dagger$ Distinguished Service Professor of Law, The University of Chicago. For their reading of a prior draft and their helpful comments, I am grateful to Frank Easterbrook, Julius Getman, Philip B. Kurland, Douglas Laycock, Paul Meier, and Daniel J. Meltzer. I wish also to thank Paul Beach and Terence Molinari, University of Chicago Law School class of 1980, for their helpful research. My shorter assessment of Weber appeared in REgulation, Sept.Oct. 1979 , at 34 .

1443 U.S. 193 (1979).

2 Civil Rights Act of 1964, §§ 701-718, 42 U.S.C. $\$ \S 2000 \mathrm{e}-2000 \mathrm{e}-17$ (1976 \& Supp. II 1978). 
ployment decisions. In addition, Weber has symbolic significance as a statement of the Court's, and thus the country's, concern for the economic welfare of blacks as a group. The Court's approach, however, may aggravate the racial polarization of our society and may obstruct the achievement of the ends that, as Justice Rehnquist implied in dissent, ${ }^{3}$ lay behind the Court's interpretation of the statute.

Weber thus invites discussion of the varied opinions that it evoked and of the reach and implications of the Court's approach. Before turning to those matters, a reference to the conflicting values and discordant regulation that led to the Weber case is appropriate.

\section{Employment Discrimination: Conflicting Themes and Discordant Commands}

The early aim of the civil rights struggle was color blindness. Government and then private employers were to remove race as an impediment to full equality of opportunity. ${ }^{4}$ That goal commanded broad support, for it was compatible with the classic values and aspirations of American society-protection of individual merit or productivity, rather than ancestry, as the determinant of individual progress. ${ }^{5}$

Later, however, some proponents of civil rights proposed a much more controversial approach, under which color was to be a factor in rationing scarce opportunities ${ }^{6}$-an approach unpalatable to some staunch proponents of color-blind, equal opportunity. ${ }^{7}$ This new color-conscious standard, for some of its adherents, was to be only, or predominantly, a tool of proof, designed to ensure that equality of opportunity was not denied by closet discrimina-

3 443 U.S. at 220-21 (Rehnquist, J., dissenting).

- See note 10, infra. See generally J. Rawls, A Theory of Justice 73 (1971).

- See Brest, The Supreme Court, 1975 Term-Foreword: In Defense of the Antidiscrimination Principle, 90 HaRv. L. Rev. 1, 6 (1976); Fiss, The Fate of an Idea Whose Time Has Come: Antidiscrimination Law in the Second Decade after Brown v. Board of Education, 41 U. CHr. L. REv. 742, 743-48 (1974) [hereinafter cited as Fiss, The Fate of an Idea Whose Time Has Come]; Fiss, A Theory of Fair Employment Laws, 38 U. CHr. L. Rev. 235, 240-44 (1971); Handlin, The Goals of Integration, 95 DaEDalus 268, 270 (1966).

- E.g., Turner \& Young, Who Has the Revolution or Thoughts on the Second Reconstruction, 94 DaEdalus 1148 (1965). See the more cautious support of color consciousness in Fiss, The Fate of an Idea Whose Time Has Come, supra note 5, at 764-70. See generally Handlin, The Quest for Equality, 1979 WASH. U. L.Q. 35, 46-50.

' See, e.g., DeFunis v. Odegaard, 416 U.S. 312, 331-34 (1974) (Douglas, J., dissenting); A. Bickel, The Morality of Consent 132-33 (1975). 
tion. ${ }^{8}$ For others, color consciousness was justified by additional and independent considerations. Since stigma and deprivation had been group based and had present consequences, current compensatory action should, it was argued, also be a function of group membership. ${ }^{\ominus}$ Such group relief would also fit into a general redistributive strategy, however crude, since blacks as a group ${ }^{10}$ were relatively poor or "disadvantaged." Finally, rationing by color would, some thought, serve to promote social peace by showing that discrimination was receding and by giving blacks a bigger share of the national pie. ${ }^{11}$

It seems clear that in Title VII Congress enacted a color-blind standard that, in general, was to protect whites as well as blacks against discrimination in employment. Nevertheless, it was also clear that color-blind standards that screen out blacks might, if mechanically applied under Title VII, become proxies for racial discrimination. ${ }^{2}$ Such ostensibly color-free standards that were ex-

- This purpose was reflected in the hospitality ultimately extended by the Supreme Court to statistical proof in Title VII cases. E.g., Hazelwood School Dist. v. United States, 443 U.S. 299, 307-08 (1977). See also EEOC v. Local 638, Sheet Metal Workers' Int'l Ass'n, 532 F.2d 821, 827 (2d Cir. 1976); Local 53, Int'l Ass'n of Heat \& Frost Insulators v. Vogler, 407 F.2d 1047, 1055 (5th Cir. 1969) (imposing color-conscious hiring remedies, in part because of judicial doubts that offending employers or unions would obey the law absent such compulsion).

- See, e.g., Brest, supra note 5, at 41-42, 50-52; Nickel, Discrimination and Morally Relevant Characteristics, in Reverse Discrimination 288 (B. Gross ed. 1977); Nickel, Preferential Policies in Hiring and Admissions: A Jurisprudential Approach, 75 Colum. L. REv. 534, 537-39 (1975); Schwartzbaum, In Search of a Constitutional Right to Federal Compensation for the Black and Poor, 15 How. L.J. 590 (1969). For a systematic examination of the general issues involved, see B. BitTker, The Case for Black Reparations (1973); A. Goldman, Justice and Reverse Discrimination (1979).

10 Although I have referred to the protection of "blacks," the antidiscrimination standard enacted into Title VII was much broader, reflecting the fact that members of other groups in the United States had been the victims of discrimination-albeit of varying intensity and duration. Accordingly, Title VII sought to protect not only blacks but members of all races, various religious groups, and women. See notes 79-81 infra. Consequently, the Act created obstacles to special programs of preferences for blacks and other "protected groups." In the ensuing discussion, the context will make it clear when "blacks" is used in its narrowest sense and when it is used as a proxy for members of all groups protected by Title VII.

11 Regents of the Univ. of Cal. v. Bakke, 438 U.S. 265, 400-02 (1978) (opinion of Marshall, J.); Jones, On the Justifiability of Reverse Discrimination, in Reverse DIscriminaTION, supra note 9, at 348, 348-49; Nickel, Preferential Policies in Hiring and Admissions: A Jurisprudential Approach, supra note 9, at 534, 539-42.

${ }_{12}$ See, e.g., United States v. Sheet Metal Workers Local 36, 416 F.2d 123, 129-30 (8th Cir. 1969) (requirement of work experience with particular employers who had not previously hired blacks). See also Local 53, Int'l Ass'n of Heat \& Frost Insulators v. Vogler, 407 F.2d 1047, 1054 (5th Cir. 1969) (nepotistic requirements in predominantly white work force). 
clusionary in effect and that lacked a business justification were in fact struck down. ${ }^{13}$ It seemed a short step from that position to one that permitted a "prima facie" case, ${ }^{14}$ or, indeed, a violation of $\mathrm{Ti}$ tle VII, to be established by recourse to statistics showing a racial imbalance in a work force. As a result, judicial interpretations of the statute, coupled with related executive policies, reveal a continuing tension between demands for equality of opportunity and demands for equality of result. These developments necessarily put pressure on employers to avoid the risk of incurring Title VII liability by adopting race-conscious employment systems ${ }^{15}$ - a practice that led to the Weber litigation.

\section{A. Judicial Ambivalence}

In Griggs v. Duke Power Co., ${ }^{16}$ the Supreme Court, in its first interpretation of Title VII, gave important support to the use of evidence of statistical imbalance; it emphasized the legal significance of employment criteria that had a disparate racial impact, even though those criteria were facially neutral and had some functional justification. For our immediate purposes, three aspects of Griggs are worth noting. First, without defining "discrimination," the Court made it clear that an employer's good faith in using a particular selection process-such as standardized, professionally developed tests-would not necessarily exclude a finding of "discrimination" if the result was disqualification of "a markedly disproportionate number of Negroes."17 The Act proscribes not only overt discrimination but also, as the Court put it, practices

that are fair in form, but discriminatory in operation. The touchstone is business necessity. If an employment practice

is See cases cited note 12 supra.

14 In pattern-and-practice suits, the Supreme Court has ruled that work-force statistics could establish a prima facie case. See Hazelwood School Dist. v. United States, 433 U.S. 299, 307-08 (1977) ("gross statistical disparities"); International Bhd. of Teamsters v. United States, 431 U.S. 324, 339-40, 339 n.20 (1977). In neither Hazelwood nor Teamsters, however, did the government rely solely on statistics.

15 See, e.g., Parham v. Southwestern Bell Tel. Co., 433 F.2d 421, 426 (8th Cir. 1970). This crude approach is called into question by Hazelwood School Dist. v. United States, 433 U.S. 299 (1977), and United Air Lines, Inc. v. Evans, 431 U.S. 553 (1977). See generally B. Schlei \& P. Grossman, Employment Discrimination Law 305 (Supp. 1979). See also New York City Transit Auth. v. Beazer, 440 U.S. 568 (1979).

18401 U.S. 424 (1971).

17 Id. at 429. 
which operates to exclude Negroes cannot be shown to be related to job performance, the practice is prohibited.

.. . Congress directed the thrust of the Act to the consequences of employment practices, not simply the motivation. ${ }^{18}$

Second, the Court concluded that Congress had "placed on the employer the burden of showing that any given requirement" that a disproportionately large number of blacks could not meet had "a manifest relationship to the employment in question."19 With respect to standardized tests, the Court deferred to the Equal Employment Opportunity Commission's stringent guidelines regarding validation. ${ }^{20}$ Thus, the Court not only imposed a heavy burden of persuasion on employers using tests with racially disparate results, it also raised a serious question as to whether such tests would ever withstand legal scrutiny. ${ }^{21}$ These exacting prerequisites for using "objective criteria," together with the use of statistics showing racial imbalance to establish a prima facie case, generated additional "legal" pressure on employers to adopt race-conscious hiring systems. ${ }^{22}$

Finally, Griggs was noteworthy because the Court failed to acknowledge that its approach to testing implicitly rejected, or at least collided with, the principle of color blindness. On the contrary, the Court proclaimed the color-free theme of Title VII:

[T] $\mathrm{Te}$ Act does not command that any person be hired simply because he was formerly the subject of discrimination, or because he is a member of a minority group. Discriminatory preference for any group, minority or majority, is precisely

18 Id. at $431-32$ (emphasis in original).

19 Id. at 432 (emphasis added).

${ }^{20}$ Id. at 433-34.

${ }^{21}$ See, e.g., Vulcan Soc'y of N.Y. City Fire Dep't, Inc. v. Civil Serv. Comm'n, 490 F.2d 387, 393-97 (2d Cir. 1973). Some employers have succeeded, however, in validating their selection procedures by showing that their tests had "content validity"- that is, they measured the ability to perform tasks that the job entailed. E.g., Coopersmith v. Roudebush, 517 F.2d 818, 824 (D.C. Cir. 1975) (legal-writing test); Smith v. St. Louis-S.F. Ry., 397 F. Supp. 580, 583-84 (N.D. Ala. 1975) ("General Clerical Test"). But see United States v. New York, 829 Gov'T EMPL. REL. REP. (BNA) 47, 69 (N.D.N.Y. Sept. 6, 1979) (despite employer's expenditure of $\$ 1,250,000$, court invalidated a test for state troopers, finding disparate impact, and disapproved a content-validation strategy for tests seeking to measure "intangible or unobservable" qualities).

22 See Developments in the Law-Employment Discrimination and Title VII of the Civil Rights Act of 1964, 84 HaRv. L. Rev. 1109, 1130 (1971) [hereinafter cited as Developments]. 
and only what Congress has proscribed. What is required by Congress is the removal of artificial, arbitrary, and unnecessary barriers to employment when the barriers operate invidiously to discriminate on the basis of racial or other impermissible classification. ${ }^{23}$

And later, the Court reaffirmed that theme:

Congress has not commanded that the less qualified be preferred over the better qualified simply because of minority origins. Far from disparaging job qualifications as such, Congress has made such qualifications the controlling factor, so that race, religion, nationality, and sex become irrelevant. What Congress has commanded is that any tests used must measure the person for the job and not the person in the abstract. ${ }^{24}$ :

Thus the Court in Griggs failed to address the technical difficulties, practical importance, or internal contradictions of its approach. Interpreting a statute drafted in terms of protecting individuals, the Court found "discrimination" because of a differential outcome for groups, notwithstanding statutory provisions designed both to protect good faith use of professionally developed tests ${ }^{25}$ and to foreclose findings of violations based solely on statistical

2s 401 U.S. at $430-31$.

${ }^{24} \mathrm{Id}$. at 436 . This statement might be read as invalidating any test on the ground that it is not job related, whether or not it has a racially disparate impact and without regard to the race of the complainant. But that approach, which would convert Title VII into a personnel code, has not, to my knowledge, been adopted. Similarly, when a test with an adverse impact on blacks is invalidated, it does not appear that a white who did poorly on the test is entitled to relief under Title VII. Cf. New York City Transit Auth. v. Beazer, 440 U.S. 568, $583 \mathrm{n} .23$ (1979) (when a prerequisite for employment is invalidated under Title VII because of its adverse impact on blacks, a white applicant, although disqualified by that requirement, presumably lacks standing to challenge it).

${ }^{23}$ Section 703(h) of Title VII, 42 U.S.C. $\$ 2000$ e-2(h) (1976) provides:

[I]t shall not be an unlawful employment practice for an employer to apply different standards of compensation, or different terms, conditions, or privileges of employment pursuant to a bona fide seniority or merit system, or a system which measures earnings by quantity or quality of production or to employees who work in different locations, provided that such differences are not the result of an intention to discriminate because of race, color, religion, sex, or national origin, nor shall it be an unlawful employment practice for an employer to give and to act upon the results of any professionally developed ability test provided that such test, its administration or action upon the results is not designed, intended or used to discriminate because of race, color, religion, sex or national origin.

The legislative history and the ambiguities of this section are considered in Developments, supra note 22 , at $1123-26$. 
imbalance. ${ }^{26}$ The employer's offense was, as noted above, not made dependent on proof of improper motive or intent. Indeed, in Griggs the Court, acknowledging the employer's good faith, ${ }^{27}$ attributed the disparate racial impact of the tests to societal discrimination that had led to inferior education for blacks. ${ }^{28}$ The Court thus required an employer, when hiring, to avoid disparate outcomes associated with societal discrimination unless he could show a "business justification" for accepting such outcomes.

The Court did not, however, spell out when such a justification would exist. Although lower courts responded with a variety of approaches, ${ }^{29}$ they tended to give narrow scope to that defense ${ }^{30}$ and, correspondingly, to subordinate considerations of cost and efficiency to the achievement of ethnic proportionality..$^{31}$ Furthermore, in Albemarle Paper Co. v. Moody, ${ }^{32}$ the Court endorsed EEOC guidelines that required differential validation of employment criteria (that is, a demonstration that such criteria were job-related)

${ }^{26}$ Section 703(j) of Title VII, 42 U.S.C. $\$ 2000 \mathrm{e}-2(\mathrm{j})$ (1976) provides:

Nothing contained in this subchapter shall be interpreted to require any employer, employment agency, labor organization, or joint labor-management committee subject to this subchapter to grant preferential treatment to any individual or to any group because of the race, color, religion, sex, or national origin of such individual or group on account of an imbalance which may exist with respect to the total number or percentage of persons of any race, color, religion, sex, or national origin employed by any employer, referred or classified for employment by any employment agency or labor organization, admitted to membership or classified by any labor organization, or admitted to, or employed in, any apprenticeship or other training program, in comparison with the total number or percentage of persons of such race, color, religion, sex, or national origin in any community, State, section, or other area, or in the available work force in any community, State, section, or other area.

27401 U.S. at 432.

28 Id. at 430 .

20 See Note, Business Necessity under Title VII of the Civil Rights Act of 1964: A NoAlternative Approach, 84 YALE L.J. 98, 99-102 (1974).

so See Comment, The Business Necessity Defense to Disparate-Impact Liability Under Title VII, 46 U. CHI. L. REv. 911, 912, 918-20 (1979).

${ }^{31}$ See id. at 918-20. This emphasis is contrary to that in the pertinent 1964 legislative history. See Note, supra note 29, at 104 n.32. It is also in tension with the theme that Weber was to emphasize- the aim of key Republican supporters of Title VII to curtail regulation. See text and note at note 91 infra. Courts expanded federal regulation when they weighed efficiency against the racial imbalances resulting from the application of facially neutral selection criteria that had some rational connection with job performance.

It should be observed, however, that Congress, in considering the 1972 amendments to Title VII, indicated that it approved of the decision in Griggs. See H.R. REP. No. 238, 92d Cong., 1st Sess. 8, 21-22 (1971), reprinted in [1972] U.S. Code CoNG. \& AD. NEws 2137, 2144, 2156-57; S. REP. No. 415, 92d Cong., 1st Sess. 5 n.1, 14 (1971). Nevertheless, the 1972 history also reflects continued opposition to quotas. See note 68 infra.

32422 U.S. 405 (1975). 
for members of minority and nonminority groups, respectively, wherever such validation was technically feasible. Those guidelines, moreover, imposed on employers the burden of showing that in a given case validation was not feasible. ${ }^{33}$ This burden was extraordinary not only because it involved proof of a negative but also because the notion of differential validity had been questioned by technical experts. ${ }^{34}$ Such considerations presumably inspired Justice Blackmun's caveat in Albemarle:

$[\mathrm{P}]$ re-employment testing, so long as it is fairly related to the job skills or work characteristics desired, possesses the potential of being an effective weapon in protecting equal employment opportunity because it has a unique capacity to measure all applicants objectively on a standardized basis. I fear that a too-rigid application of the EEOC Guidelines will leave the employer little choice, save an impossibly expensive and complex validation study, but to engage in a subjective quota system of employment selection. This, of course, is far from the intent of Title VII. ${ }^{35}$

Nevertheless, four years later in Weber the Justice was to join in upholding the very selection system that he had decried in Albemarle.

\section{B. Color-Conscious Remedies}

Soon after Albemarle, the Court in McDonald $v$. Santa Fe Trail Transportation Co. ${ }^{36}$ speaking through Justice Marshall, indicated that a subjective quota system would violate both Title VII and section 1981 of Title $42 .{ }^{37}$ To be sure, that case dealt with an

ss Id. at 435 .

s4 See id. at 452 n.3 (Burger, C.J., concurring in part and dissenting in part); American Psychological Ass'n Task Force on Employment Testing of Minority Groups, Job Testing and the Disadvantaged, 24 AM. Psychologist 637, 641-42 (1969), cited in United States v. Georgia Power Co., 474 F.2d 906, 914 n.8 (5th Cir. 1973).

${ }^{35} 422$ U.S. at 449 (Blackmun, J., concurring). Despite the risks highlighted by Justice Blackmun, statistical evidence has a proper and important role to play under Title VII, as the Court observed in International Bhd. of Teamsters v. United States, 431 U.S. 324, 339 (1977). But, as the Court also observed, careful and informed scrutiny is necessary in order to prevent "statistics" from degenerating into a sloppy substitute for reliable proof of discrimination. Id. at 340. A full treatment of the use and abuse of statistical proof in this context and the fitness of courts to handle it is beyond the scope of this article.

so 427 U.S. 273 (1976).

s7 Id. at 280, 286-87. The Court was unanimous on the Title VII ruling, but Justices White and Rehnquist dissented from the ruling on section 1981. Id. at 296 (Rehnquist, J., dissenting). 
issue quite different from that of the propriety of a quota system, namely, an allegation that two white employees had been fired for misappropriation while an equally guilty black had been retained. The Court, however, reaffirmed the position announced in Griggs that Title VII prohibited "[d]iscriminatory preference for any [racial] group, minority or majority." broad antidiscrimination principle has been espoused by the EEOC and was in accord with the uncontradicted legislative history of Title VII. ${ }^{3 \theta}$ The Court, however, carefully observed: "we do not consider here the permissibility of [an affirmative action program] whether judicially required or otherwise prompted."10

The Court's reservation implied that some judicial remedies for violations of Title VII, among other forms of "affirmative action,"41 might collide with the sweeping race-free standard previously proclaimed by the Court. In this connection, two kinds of judicial remedies should be distinguished. The first, which is wholly compatible with a race-free standard, attempts to give an identifiable victim of discrimination make-whole relief with respect to lost pay and competitive seniority status. ${ }^{42}$ Such restorative justice may, of course, encroach on the interests of other employees $^{43}$ - white or black-but that consequence does not flow from racial considerations as such; make-whole relief affects incumbents, as well as victims, without regard to their race.

The second kind of remedy is of a wholly different character; it requires the offending employer to hire or promote ${ }^{44}$ a fixed per-

ss Id. at 279 (footnote and citation omitted) (emphasis in original).

30 Id. at 279-80. The employer understandably had conceded that " 'across-the-board discrimination in favor of minorities could never be condoned consistent with Title VII'" but had sought to distinguish " such discrimination . . . in isolated cases which cannot reasonably be said to burden whites as a class unduly." Id. at $280 \mathrm{n} .8$ (quoting Brief for Respondent Santa Fe at 20).

40 Id.

4 See note 58 infra.

12 See Franks v. Bowman Transp. Co., 424 U.S. 747 (1976); Albemarle Paper Co. v. Moody, 422 U.S. 405 (1975).

13 Concern about such encroachment led Justice Powell (with whom Justice Rehnquist joined) to dissent in Franks v. Bowman Transp. Co., 424 U.S. 747, 781 (1976), in protest of what he deemed the Court's virtually automatic requirement of retroactive competitive seniority relief to victims of post-Act discrimination and the corresponding disregard of the interests of innocent employees whose relative seniority would thereby be reduced. Chief Justice Burger generally agreed with that dissent but went even further, questioning "competitive-type seniority relief at the expense of wholly innocent employees" and urging instead an award of "front pay" for the victim of discrimination. Id. at 780-81 (Burger, C.J., concurring in part and dissenting in part).

14 The Second Circuit has developed a questionable distinction between quotas in hir- 
centage of blacks in a given period of time. ${ }^{45}$ Such a remedy benefits individuals without regard to whether they themselves have been the victims of unlawful discrimination. Such color-conscious relief, although it goes beyond the needs of restorative justice for individual victims of statutory violations, has been supported by a cluster of considerations. First, since the actual victims were injured because of their membership in a group, a group-oriented remedy appears proper. ${ }^{48}$ Second, a group remedy sometimes seems necessary to deal with recalcitrant recidivists ${ }^{47}$ and to avoid difficulties of proof inherent in determining compliance with a general injunctive order against discrimination, ${ }^{48}$ or to show historically victimized groups that old patterns of discrimination have ended. ${ }^{49}$ Finally, this judicial approach underscores the importance of

ing (permissible) and quotas in promotions (impermissible). See generally Bridgeport Guardians, Inc. v. Members of Bridgeport Civil Serv. Comm'n, 482 F.2d 1333 (2d Cir. 1973).

${ }_{4 B}$ For a survey of the rationales for judicially imposed remedial quotas, see Greenawalt, The Unresolved Problems of Reverse Discrimination, 67 CalIF. L. REv. 87, 95-98 (1979).

4s See, e.g., Boston Chapter, NAACP, Inc. v. Beecher, 504 F.2d 1017, 1027 (1st Cir. 1974) (42 U.S.C. $\$ \S 1981,1983$ (1976)), cert. denied, 421 U.S. 910 (1975); League of United Latin Am. Citizens v. City of Santa Ana, 410 F. Supp. 873, 911 (C.D. Cal. 1976) (Title VII); Arnold v. Ballard, 390 F. Supp. 723, 736 (N.D. Ohio 1975) (42 U.S.C. $\S \S 1981,1983$ (1976) and U.S. Const. amend. XIV) ("The need to remedy past injuries to the black community takes precedence over the hopes of [white applicants]").

4 See, e.g., United States v. City of Chicago, 549 F.2d 415, 437 (7th Cir.), cert. denied, 434 U.S. 875 (1977); EEOC v. Local 638, Sheet Metal Workers' Int'l Ass'n, 532 F.2d 821, 826-27 (2d Cir. 1976); Morrow v. Crisler, 491 F.2d 1053, 1056 (5th Cir.) (en banc), cert. denied, 419 U.S. 895 (1974); Local 53, Int'l Ass'n of Heat \& Frost Insulators v. Vogler, 407 F.2d 1047, 1055 (5th Cir. 1969). Cf. NAACP v. Allen, 493 F.2d 614, 619-21 (5th Cir. 1974) (need for quotas in suits brought under the fourteenth amendment). In other cases, courts have refused to require employment of specified percentages of minorities until the employer again indicates a refusal to comply with the law. See, e.g., Wade v. Mississippi Coop. Extension Serv., 372 F. Supp. 126, 146 (N.D. Miss. 1974), vacated, 528 F.2d 508 (5th Cir. 1976); Western Addition Community Organization v. Alioto, 360 F. Supp. 733 (N.D. Cal. 1973).

48 Nevertheless, in proceedings for criminal contempt, the qualified right to a jury trial and the heavier burden of persuasion (proof beyond a reasonable doubt rather than by clear and convincing evidence) might complicate enforcement where standards for compliance are not clear.

40 See, e.g., Morrow v. Crisler, 491 F.2d 1053, 1056 (5th Cir.) (en banc), cert. denied, 419 U.S. 895 (1974). Cf. Carter v. Gallagher, 452 F.2d 315, 328-31 (8th Cir. 1971) (rehearing en banc) (suit based on 42 U.S.C. $\$ 1981$ (1976) and U.S. CoNsT. amend. XIV), cert. denied, 406 U.S. 950 (1972).

Perhaps the justification most frequently urged by courts for "remedial" quotas is the need to eliminate the "present effects" of past discrimination. See, e.g., Rios v. Steamfitters Local 638, 501 F.2d 622, 628-30 (2d Cir. 1974); United States v. Local 212, IBEW, 472 F.2d 634, 636 (6th Cir. 1973); United States v. Ironworkers Local 86, 443 F.2d 544, 553 (9th Cir.), cert. denied, 404 U.S. 984 (1971). Courts do not specify what effects they seek to eliminate, but the principal "effects" appear to be statistical imbalances in work forces that are 
the statutory policy of protecting blacks and reinforces the deterrent effect of granting back pay liability to identifiable victims of discrimination. Such considerations lay behind the virtually unanimous view of the lower federal courts that Title VII authorized them to order violators to adopt group remedial preferences ${ }^{50}-a$ view that the Supreme Court has not yet considered. ${ }^{.1}$

This view, however, undercuts the principle of color blindness and thus involves serious questions of statutory construction ${ }^{\mathrm{52}}$ and equitable treatment of white candidates for future jobs. Such candidates, who had not directly benefited from a particular employer's discrimination against blacks, would, by virtue of remedial quotas, be handicapped in job competition with blacks who had not been directly injured by the employer's violations. Furthermore, this absence of an individuated connection between remedy, on the one hand, and benefit and injury, on the other, ${ }^{, 3}$ makes it

ascribed to societal discrimination and that would continue even after discrimination ended. Even when such imbalances are evidence of past discrimination by the employer involved, quota hiring for the future will only fortuitously reach the actual victims of such discrimination. In fact, as Weber illustrates, the beneficiaries could be wholly distinct from those previously discriminated against. See text and notes at notes 137-146 infra.

so For a vigorous exposition of the contrary view, see Judge Hays's dissent in Rios v. Steamfitters Local 638, 501 F.2d 622, 634 (2d Cir. 1974). Accord, Brief for Petitioner United Steelworkers of America at 80-82, 82 n.167, United Steelworkers v. Weber, 443 U.S. 193 (1979). See text and notes at notes 137-153 infra.

s1 See text and notes at notes 99-101 infra.

s2 Section 706(g) of Title VII, 42 U.S.C. $\$ 2000 \mathrm{e}-5(\mathrm{~g})$ (1976), forbids courts to grant affirmative relief to individuals who were not discriminated against by a particular employer. This limitation (on judicial power) was repeatedly discussed in the 1964 debates. E.g., 110 Cong. Rec. 6001 (1964) (remarks of Sen. Humphrey) ("The only thing that the court would do would be to ask the defendant to cease and desist, to tell him to stop this practice, if it can be proved that the practice has been unlawful"); id. at 6549 (remarks of Sen. Humphrey); id. at 6563 (remarks of Sen. Kuchel); id. at 6566 (interpretive memorandum by Republicans on House Judiciary Committee).

The Congress in 1972 amended section $706(\mathrm{~g})$ so as to empower a court to grant "any . . . equitable relief . . . the court deems appropriate." Equal Employment Opportunity Act of 1972, Pub. L. No. 92-261, § 4(a), 86 Stat. 103 (current version at 42 U.S.C. § 2000e-5(g) (1976)). Nevertheless, the legislative history indicates that the increased discretion granted to courts was not designed to eliminate preexisting restrictions on remedial quotas. Indeed, the House Conferees insisted on the retention of the 1964 restrictions. See H.R. REP. No. 899, 92d Cong., 2d Sess. 18-19 (1972), reprinted in [1972] U.S. Code ConG. \& AD. NEws $2179,2183$.

${ }_{53}$ There was a similar lack of connection between individual victims and the individual beneficiaries of remedies in the school desegregation cases. See, e.g., Swann v. CharlotteMecklenburg Bd. of Educ., 402 U.S. 1, 16 (1971). But in those cases, courts possessed broad authority to remedy violations of the Constitution and were free from the difficulties posed by the language and history of Title VII. For other differences in the two situations, see Greenawalt, supra note 45, at 94-95. For a study of the interplay of the Court's recent school desegregation cases and Weber, see Kitch, The Return of Color-Consciousness to the 
difficult to distinguish such judicially imposed remedial group quotas from similar measures directed at societal discrimination-measures which Congress prohibited its enforcement agencies from employing. ${ }^{54}$ In addition, such remedial group preferences are not easily distinguishable from the racial preferences condemned by the Court in Griggs and Santa Fe. ${ }^{.5}$

For our immediate purposes, there is no need to pursue these remedial questions. It is enough to note that judicial resort to remedial group preferences presumably stimulated employers, on their own initiative, to adopt similar measures in order to redress racial imbalances among their employees, thereby reducing the risk that possibly more draconian remedies would be judicially imposed.

\section{Executive Ambivalence: Executive Order 11,246}

Similar pressures for preferential hiring arose under Executive Order $11,246^{56}$ and related regulations, which apply to government contractors. The Order, issued by President Johnson in $1965,{ }^{57}$ required government contracts to include an "affirmative action clause" ${ }^{18}$ in addition to a nondiscrimination clause. In 1967, Execu-

Constitution: Weber, Dayton, and Columbus, 1979 Sup. CT. Rev. 1.

s4 See Note, supra note 29 , at 106 \& n.41.

${ }^{55}$ In both situations preferences are being granted not to make whole an identifiable victim but to alleviate societal discrimination, or to improve an employer's racial statistics. The common feature is the allocation of jobs on the basis of race. To be sure, judicial action seems less ad hoc. Furthermore, courts would presumably be more sensitive than firms to the equities of others affected by their measures. But in an adversary system, and especially when consent decrees are involved or when the defendants welcome the shield of a court order, judicial concern for the diffused interests of members of the general public could be quite perfunctory.

Bo 3 C.F.R. 339 (1964-1965 Compilation), reprinted as amended in 42 U.S.C. \& $2000 \mathrm{e}$ (1976).

${ }^{87}$ For a discussion of predecessor orders, see K. McGuiness, Preferential Treatment in Employment 11-18 (1977); Nash, Affirmative Action under Executive Order 11,246, 46 N.Y.U. L. REv. 225, 225 n.2 (1971).

ss The contractor will take affirmative action to ensure that applicants are employed, and that employees are treated during employment, without regard to their race, creed, color, or national origin.

Exec. Order No. 11,246, § 202(1), 3 C.F.R. 339, 340 (1964-1965 Compilation), reprinted as amended in 42 U.S.C. $\$ 2000$ e (1976). "Affirmative action" includes a broad range of measures, such as (1) efforts to diversify applicant pools ("affirmative recruitment"); (2) efforts to neutralize bigotry in hiring and promotion; and (3) more or less explicit quotas. Each of these measures may be essentially "voluntary" or may result from pressures from a variety of sources, including private groups, government procurement officers, potential litigants under Title VII, conciliation agreements, consent decrees, and direct judicial orders.

Initially, "affirmative action" was viewed essentially as consisting of both "affirmative 
tive Order $11,375^{\circ 9}$ added sex to the characteristics that were not to be used as a basis for employment discrimination.

Executive Order 11,246 did not, however, define "affirmative action," and contradictions in interpretation soon arose. Thus, while nondiscrimination was the formal standard, affirmative action did not "necessarily" include preferential treatment-but it did require that in some way the proper "results" be achieved. ${ }^{60}$

In 1970, new regulations reiterated the emphasis on results, stating:

An affirmative action program is a set of specific and resultoriented procedures to which a contractor commits itself to apply every good faith effort. The objective of those procedures plus such efforts is equal employment opportunity. Procedures without effort to make them work are meaningless; and effort, undirected by specific and meaningful procedures, is inadequate. ${ }^{61}$

Equality of opportunity, insofar as it meant decisions based on competence, was to be superseded by or measured by equality of outcome. An employer's compliance as a practical matter was to be ascertained by comparing the representation of minorities in his work force with their representation in some population or labor market. ${ }^{62}$ The agencies responsible for compliance pressed contrac-

recruitment" and efforts to remove prejudice from employment decisions, and did not encompass discrimination in hiring or promotion. See Allen-Bradley Co., OFCC No. 101-68 (Dec. 17, 1968) (on file with The University of Chicago Law Review), plan accepted by the Secretary of Labor, [1975] EMPL. Prac. (CCH) II 1634 (Aug. 8, 1969). Although affirmative recruitment might, under some circumstances, generate problems under Title VII, such recruitment, as well as antidiscrimination training, is in general wholly consonant with the language and purposes of Title VII.

so 3 C.F.R. § 684 (1966-1970 Compilation).

so See, e.g., Statement of Edward C. Sylvester, Jr., Director of OFCC (Jan. 1967), quoted in R. Nathan, Jobs AND Civil Rights 93 (1969):

I would say that in a general way, affirmative action is anything that you have to do to get results. But this does not necessarily include preferential treatment. The key word here is "results." ...

Affirmative action is really designed to get employers to apply the same kind of imagination and ingenuity that they apply to any other phase of their operation.

141 C.F.R. $\S 60-2.10$ (1979). This rule was promulgated on Feb. 5, 1970, in 35 Fed. Reg. 2586, 2587 (1970).

2 Cases arising under Title VII were to refine the population(s) appropriate for determining whether an employer's work force exhibited the right proportions. See Furnco Constr. Corp. v. Waters, 438 U.S. 567, 571-72 (1978) (disparate treatment; qualified area work force); Hazelwood School Dist. v. United States, 433 U.S. 299, 308 (1977) (disparate treatment; qualified workers in relevant labor market); Griggs v. Duke Power Co., 401 U.S. 424, 430 (1971) (disparate impact; pool of applicants). See also Hallock, The Numbers 
tors for goals and timetables or "commitments" to increase minority employment, even though there had been no showing of past or present discrimination by the contractors. ${ }^{63}$ Despite the pressure for racially oriented decisions exerted by these ill-defined extrastatutory requirements, the regulations contained the usual contrapuntal disclaimer: The use of goals and timetables "is not intended . . . to discriminate against any applicant or employee because of race, color, religion, sex or national origin." claimer, a former Under Secretary of Labor later conceded that "goals" were ill-disguised quotas..$^{65}$

\section{The 1972 Amendments to Title VII}

In amending Title VII in 1972, the Senate rejected a proposed amendment that was aimed at preventing official pressure for hiring quotas: it would have subjected Executive Order 11,246 to the limitation embodied in section 703(j) of Title VII. ${ }^{68}$ That provision declared that the Act should not be interpreted to require preferential treatment for certain protected groups because of their underrepresentation in an employer's work force. ${ }^{67}$ There is no need here to speculate on the meaning of the Senate's rejection of this amendment. Whatever purpose is imputed to the Senate, the action of one house with respect to the proposed amendment could not repeal any consensus against compulsory quotas that was reflected in the passage of the 1964 Act. Furthermore, other aspects

Game-The Use and Misuse of Statistics in Civil Rights Litigation, 23 VILL. L. REv. 5, 1534 (1977).

"As According to an Under Secretary of Labor, such pressure on "not guilty" contractors was justified on the ground that "they are required under the Executive Order to go beyond, to provide affirmative action." Hearings on S. 2515, S. 2617 \& H.R. 1746 Before the Subcomm. on Labor of the Senate Comm. on Labor and Public Welfare, 92d Cong., 1st Sess. 88 (1971) (statement of Laurence H. Silberman), quoted in K. McGuiness, supra note 57, at 31.

84 41 C.F.R. $\S 60-2.30$ (1979).

os See Silberman, The Road to Racial Quotas, Wall St. J., Aug. 11, 1977, at 14, col. 4.

es See note 26 supra.

e7 See 118 Cong. Rec. 4917 (1972).

Previously, both houses had defeated efforts to merge the OFCC into the EEOC. Although such proposals had been coupled with bans on hiring quotas, see Comment, The Philadelphia Plan: A Study in the Dynamics of Executive Power, 39 U. CHI. L. REv. 723, 754 (1972), the defeat of such proposals could be viewed both as an oblique approval of the Philadelphia Plan, see Contractors Ass'n v. Secretary of Labor, 442 F.2d 159 (3d Cir.), cert. denied, 404 U.S. 854 (1971), and as a refusal to impose an absolute prohibition against the use of goals or quotas as tools of an antidiscrimination program. Nevertheless, ambiguity resulted from the failure to consider such goals separately rather than as part of a program that had included dismantling of the executive program. See Comment, supra. 
of the 1972 legislative action make it clear that Congress did not then recede from, but rather reiterated, its opposition to compulsory quotas. ${ }^{68}$ Nevertheless, Congress did not specifically foreclose the use of all color-conscious standards or remedies by courts, nor did it seek to block the continued judicial development of "discrimination" beyond the idea of disparate or unequal treatment of individuals. ${ }^{69}$ The congressional action in 1972 thus did not provide a clear basis for resolving the developing contradictions and enigmas in the area of employment discrimination.

Similarly, judicial developments after 1972, but before Weber, were not especially helpful. Indeed, Regents of the University of California v. Bakke, ${ }^{70}$ which sorely divided the Court, appeared to highlight the risk faced by employers that Title VII might be read as banning explicit racial preferences-at least in the absence of official findings of unlawful conduct by the employer involved. ${ }^{71}$

\section{The Weber CASE}

The discordant elements of Title VII and Executive Order 11,246 led to the Weber litigation. They prompted Kaiser and the Steelworkers to adopt a racially preferential training program, in the hope of avoiding Title VII litigation by blacks as well as additional pressure from federal contract-compliance officials. At the same time, the statute and regulations gave Brian Weber grounds for challenging that program as it was applied to Kaiser's plant at Gramercy, Louisiana.

\footnotetext{
ss Such opposition appeared to be an important factor in the congressional refusal in 1972 to grant cease-and-desist authority to the EEOC. Note, supra note 29 , at $106 \&$ n. 41 . The 1972 debates also reflected concern over quotas that were not directly imposed by the EEOC but were adopted in order to avoid possible harassment by that agency. The 1964 proposal to empower the EEOC to issue orders was not reported out of the House Judiciary Committee; it was urged that such authority would retard voluntary conciliation and that the district courts would give employers fairer treatment. See Vaas, Title VII: Legislative History, 7 B.C. Indus. \& CoM. L. REv. 431, 435-37 (1966).

69 See International Bhd. of Teamsters v. United States, 431 U.S. 324, $391-93$ (1977) (Marshall, J., concurring in part and dissenting in part). Furthermore, the 1972 legislative history reflected a heightened awareness of the need to deal with so-called systemic discrimination. Cf. 118 Cong. REc. 4942 (1972) (analysis of S. 2515 read into the record by Sen. Williams). Congress not only expressly approved the result in Griggs, see note 31 supra, but also generally endorsed judicial interpretations of the 1964 Act. 118 CoNG. REc. 7166-69 (1972) (Section-by-Section Analysis of H.R. 1746, The Equal Employment Opportunity Act of 1972). See also Teamsters, 431 U.S. at 391-93.

70438 U.S. 265 (1978). See generally Symposium: Regents of the University of California v. Bakke, 67 CALIr. L. REv. 1, 1-189 (1979).

72 See 438 U.S. at 301-02 (opinion of Powell, J.).
} 
Kaiser opened its Gramercy plant in 1958. By the 1970s, blacks constituted approximately $39 \%$ of the labor force in the Gramercy area, but less than $15 \%$ of Kaiser's work force and less than $2 \%$ of its craft workers. Kaiser had hired only craftsmen (carpenters, electricians, machinists, and so on) with five years prior industrial experience-experience rarely possessed by blacks, who had previously been excluded from craft unions. As a result, Kaiser's efforts to recruit trained black craftsmen-although apparently bona fide-had been largely ineffective.

In 1974, the collective agreement between Kaiser and the Steelworkers addressed that recruitment problem; it provided for a new in-plant craft training program at Gramercy (as well as at Kaiser's other aluminum and container plants), to which at least one black was to be admitted for every white until the percentage of black craft workers equalled the percentage of blacks in the Gramercy work force, or $39 \% .{ }^{22}$ Black and white applicants were to be chosen on the basis of relative seniority within their racial group. ${ }^{73}$

In 1974, Brian Weber, a white employee at Gramercy, was turned down for three skilled training programs even though he had more seniority than two successful black candidates. He thereupon brought a class action, challenging the $50 \%$ minority admission quota as a violation of Title VII. The federal district court upheld his claim and enjoined the use of race as a criterion for admission to the program. ${ }^{74}$ The Court of Appeals for the Fifth Circuit, with Judge Wisdom dissenting, affirmed. ${ }^{75}$ That court em-

72 This program referred to "minority" rather than "black" employees and used "minority" as defined in the reporting requirements of the EEOC, Weber v. Kaiser Aluminum \& Chem. Corp., 415 F. Supp. 761, 763 (E.D. La. 1976). This standard is difficult to pin down; there does not appear to be an EEOC regulation defining "minority" for purposes of reporting. According to the Steelworkers' brief to the Supreme Court, minority beneficiaries have been and are likely to be black; hence "minority" and "black" were used interchangeably. Furthermore, the program also established craft-training goals for women, "although successful female bidders for such vacancies regardless of race may be counted against the $50 \%$ reserved for minorities." Brief for Petitioner United Steelworkers of America at 2 n.1, Weber, 443 U.S. 193 (1979).

7s The trial court concluded that there was no evidence that Kaiser had developed this program with a view to correcting the effects of prior discrimination at any of its plants. Weber v. Kaiser Aluminum \& Chem. Corp., 415 F. Supp. 761, 764 (E.D. La. 1976). The court, on the contrary, found that the primary motivation of the company-a contractor with the federal government- "appears [to have been] satisfying the requirements of OFCC, and avoiding vexatious litigation by minority employees." Id. at 765 .

${ }^{74}$ Id. at 770.

${ }^{7 s}$ Weber v. Kaiser Aluminum \& Chem. Corp., 563 F.2d 216 (5th Cir. 1977). 
phasized the district court's finding that Kaiser had not been guilty of any past employment discrimination at its Gramercy plant. ${ }^{76}$ The Supreme Court, as we already know, upheld the Kaiser plan and reversed the decision of the court of appeals.

\section{A. The Opinions}

1. Justice Brennan. Speaking for the Court, Justice Brennan passed over the more candid and superficially appealing argument advanced by Kaiser and the Department of Justice (as amicus curiae) and accepted by Judge Wisdom, dissenting below. ${ }^{77}$ That argument-to which we shall return-had stressed the need to uphold programs such as Kaiser's in order to promote voluntary compliance with Title VII while protecting employers and unions from the intolerable dilemma we have already mentioned-the risk of litigation by blacks if employers failed to adopt preferential programs and by whites if they did. ${ }^{78}$

Instead, Justice Brennan chose to rely on that part of the Steelworkers' argument that stressed, not the employer's dilemma generated by regulatory developments, but rather the original meaning of the Act, read in light of its legislative history. Three provisions of Title VII (sections $703(\mathrm{a})(1),{ }^{78} 703(\mathrm{a})(2)^{80}$ and 703(d) ${ }^{81}$ ) appeared, however, to foreclose, with unusual clarity, the Court's construction. A reference to those provisions is appropriate at this point because they shaped both Justice Brennan's support-

76 Id. at 224. The court also stressed the finding below that societal discrimination had no effect on the seniority of any party to the litigation. Id. at 226.

${ }_{77}$ Id. at 230 (Wisdom, J., dissenting).

78 Id. (Wisdom, J., dissenting).

70 It shall be an unlawful employment practice for an employer-(1) to fail or refuse to hire or to discharge any individual, or otherwise to discriminate against any individual with respect to his compensation, terms, conditions, or privileges of employment, because of such individual's race, color, religion, sex, or national origin . . . .

42 U.S.C. \& 2000e-2(a)(1) (1976) (emphasis added).

so It shall be an unlawful employment practice for an employer- . . . (2) to limit, segregate, or classify his employees or applicants for employment in any way which would deprive or tend to deprive any individual of employment opportunities or otherwise adversely affect his status as an employee, because of such individual's race, color, religion, sex, or national origin.

Id. § 2000e-2(a)(2) (emphasis added).

${ }^{81}$ It shall be an unlawful employment practice for any employer, labor organization, or joint labor-management committee controlling apprenticeship or other training or retraining, including on-the-job training programs to discriminate against any individual because of his race, color, religion, sex, or national origin in admission to, or employment in, any program established to provide apprenticeship or other training.

Id. $\$ 2000 \mathrm{e}-2(\mathrm{~d})$ (emphasis added). 
ing argument and the differing approaches of some of his brethren. ${ }^{82}$

Section 703(a), the central provision of the Act, appears to outlaw all discrimination against an individual on grounds of race. Although there is no definition of "discrimination" in that section-or, indeed, anywhere in the statute-the pertinent internal context indicates that to impose any disadvantage on an individ$\mathrm{ual}^{\mathrm{83}}$ in hiring, employment, or training, on the basis of race, is "to discriminate" within the meaning of section 703(a)(1). Furthermore, section 703(a)(2), which covered Brian Weber's complaint, plainly makes it unlawful for an employer to classify his employees on the basis of race. In short, the statutory language on its face seeks to insulate all employment decisions against the influence of racial considerations. ${ }^{\mathbf{8 4}}$

Consequently, Justice Brennan could scarcely find any ambiguity in the terms of the statute. On the contrary, he virtually conceded that Brian Weber's claim was supported by a literal interpretation of the Act. But that claim was, the Justice concluded, incompatible with the Act's spirit and purpose: ${ }^{85}$ Congress's pri-

${ }^{82}$ Also appropriate is a characteristically sage observation by Professor Corbin in a different context:

[A]n interpretation is not to be scorned merely because it seems obvious; words are, indeed, not to be condemned because they seem plain and clear and unambiguous. Clarity of expression is a merit-a somewhat unusual one. There are cases in which the words of the writing are ambiguous to nobody ....

Corbin, The Interpretation of Words and the Parol Evidence Rule, 50 CoRNELL L.Q. 161, 172 (1965).

${ }^{83}$ In Los Angeles Dep't of .Water \& Power v. Manhart, 435 U.S. 702 (1978), Justice Stevens, speaking for the Court, declared: "The statute's focus on the individual is unambiguous." Id. at 708. Although the Court was divided in Manhart, none of the three other opinions questioned that proposition. See also Regents of the Univ. of Cal. v. Bakke, 438 U.S. 265, 408, 416 n.19 (1978) (Stevens, J., concurring in the judgment in part and dissenting in part).

st Justice Brennan did not treat the question presented by Weber as if the operative statutory language consisted of "to discriminate," with a corresponding question as to whether "benign" or "fair" discrimination, as well as "malign" or "unfair" discrimination were outlawed. Some defenders of the result in Weber appear first to argue as if the operative proscription covered "discrimination" or "to discriminate" and then to argue that that proscription is ambiguous and should be interpreted to reach only "invidious discrimination" and not discrimination involved in an "affirmative action plan to help establish genuine racial equality." Dworkin, How to Read the Civil Rights Act, N.Y. Rev. or Books, Dec. 20, 1979, at 37. After finding ambiguity in "discrimination," Professor Dworkin urged that Weber could not properly be decided by looking only at the statutory language and subscribed in general (but not completely) to Justice Brennan's view of the legislative history and the precedents. Id. at 40-42. As shown below, Dworkin's approach is highly questionable.

${ }^{85} 443$ U.S. at 201-02. Justice Brennan quoted only two items of legislative history in 
mary aim had been to open to blacks jobs from which they had traditionally been barred. ${ }^{\mathbf{s}}$ Brian Weber's proposed interpretation was unacceptable because it would prohibit effective steps by private firms to accomplish that purpose. ${ }^{87}$ Quoting the late Senator Humphrey, the Justice observed that it would

be ironic indeed if a law triggered by a nation's concern over centuries of injustice and intended to improve the lot of those who had "been excluded from the American dream for so long," ... . constituted the first legislative prohibition of all voluntary, private, race-conscious efforts to abolish traditional patterns of racial segregation and hierarchy.$^{88}$

Justice Brennan found an additional and important justification for his position in section $703(\mathrm{j})$ of the Act, which provides that nothing in Title VII shall be interpreted to require an employer to grant preferential treatment to any individual or group because of a racial imbalance in the employer's work force. ${ }^{89}$ The Justice urged that use of "require" rather than "require or permit" shows that "Congress chose not to forbid voluntary race-conscious affirmative action" to redress racial imbalance. ${ }^{90}$ In addition, such a blanket prohibition would, he urged, conflict with the concern about excessive federal regulation that had been expressed in the legislative debates. ${ }^{91}$

support of his proposition that Congress "did not intend wholly to prohibit private and voluntary affirmative action efforts." Id. at 203-04. One was, as Justice Rehnquist observed, taken out of context and did not even deal with employment. Id. at 229 n.11 (Rehnquist, J., dissenting). The other quotation, ignored by Justice Rehnquist in his dissent, was a statement of Representative MacGregor, delivered shortly before the final vote on Title VII. See id. at 207-08 n.7. That statement, however, is so far out of step with the rest of Title VII's voluminous legislative history that it is not entitled to significant weight.

${ }^{86} \mathrm{Id}$. at 202.

s7 Id. at 204.

ss Id. (quoting 110 Cong. Rec. 6552 (1964) (remarks of Sen. Humphrey)).

s9 42 U.S.C. $\S 2000 \mathrm{e}-2(j)$ (1976). For the text of the section, see note 26 supra.

1443 U.S. at 204-06.

21 Id. at 206-07. Weber did not mention section 1981 of Title 42. That statute lacks a provision resembling section $703(\mathrm{j})$, which provides that Title VII should not be interpreted to require preferential treatment, see text at note 89 supra. This difference in the statutes appears to cast a shadow on the kind of affirmative action upheld by Weber. This difficulty apparently has led to suggestions that the Court should correct its alleged error in McDonald v. Santa Fe Trail Transp. Co., 427 U.S. 273 (1976), by now holding that section 1981, insofar as it protects whites against racially discriminatory discharge, is not within Congress's power under the thirteenth amendment. See Note, The Thirteenth Amendment and Private Affirmative Action, 89 Yale L.J. 399, 402 (1979). But even if the Court should repudiate its position in $M c D$ onald with respect to the thirteenth amendment, it could rely on the commerce clause and the fourteenth amendment as a modern constitutional foundation 
Section 703(j) also served as the basis for the Court's effort to distinguish Bakke. ${ }^{92}$ Justice Brennan sought to explain the omission of a comparable clause in Title VI of the Civil Rights Act-the Title at issue in Bakke-on the ground that Title VI had been enacted under the congressional power over federal expenditures and was intended to incorporate the equal protection standards of the fifth and fourteenth amendments, whereas Title VII had been based on the commerce power and had been designed to regulate private action. ${ }^{93}$ Given these different constitutional bases, the Justice suggested, in a footnote, that Titles VI and VII should not be read "in pari materia."94

It is convenient to indicate here why the Court's attempted distinction between Weber and Bakke is, in my opinion, a failure. The suggestion that different constitutional bases for the two titles imply different meanings for the antidiscrimination principle enacted by each of them is not supported by any functional consideration, and ignores the fact that both titles incorporated a broad antidiscrimination principle. ${ }^{95}$ Furthermore, the suggestion that interpretations of these two titles should be kept separate disregards the relationship-a relationship accepted by all the Justices in $B a k k e^{96}$-between them evidenced by their common language,

for proscribing employment discrimination against all races, including whites. To be sure, questions of construction arise when section 1981 meets programs of "reverse discrimination." But these questions are no more formidable than those involved in Weber and are likely to be dispatched in the same way.

${ }_{92}$ Regents of the Univ. of Cal. v. Bakke, 438 U.S. 265 (1978).

${ }^{93}$ See 443 U.S. at 206 n.6. The focus in Bakke was the meaning attached by Congress to the term "discriminate." In Weber, the majority largely ignored the debates that focused specifically on the meaning of that term, see, e.g., 110 CoNG. REc. 8921 (1964) (remarks of Sen. Williams).

94 443 U.S. at 206 n.6. But cf. Board of Educ. v. Harris, 444 U.S. 130 (1979) (finding, in a divided opinion, Title VII decisions apposite in interpreting a federal statute funding certain schools with special needs occasioned by desegregation programs).

25 See M. Sovern, Legal Restraints on Racial Discrimination in Employment 99-100 (1966).

${ }^{96}$ All the Justices treated decisions under Title VII as relevant to questions arising under Title VI. See 438 U.S. at 301-02 (opinion of Powell, J.); id. at 340 n.17, 353-55, 366-68 (Brennan, White, Marshall, and Blackmun, JJ., concurring in the judgment in part and dissenting in part); id. at 413 n.12, 416 n.19 (Stevens, J., joined by Burger, C.J., and Stewart and Rehnquist, JJ., concurring in the judgment in part and dissenting in part). Furthermore, Justice Stevens observed that Titles VI and VII each reflected the belief of Congress that "the principle of individual equality, without regard to race or religion," commanded a national consensus. Id. at $416 \mathrm{n} .19$ (emphasis in original). Finally, he recognized that both of these titles had a force independent of, and in addition to, that found in the Constitution. Id. at 416-17. 
purpose, and history. ${ }^{97}$

Justice Brennan explicitly declined to go beyond the case before him and to delineate the scope and limits of the principle governing the validity of voluntary preferences. ${ }^{98}$ Nor, as we will see later, did his listing of those aspects of the Kaiser-Steelworkers Union plan that in combination made for its legality do much to dissipate the murkiness inherent in the Court's avowedly ad hoc approach. Furthermore, Justice Brennan expressly refused to pass on the legality of court-ordered quotas as a remedy for proven violations of the Act, ${ }^{98}$ or to consider ${ }^{100}$ the effect of Executive Order $11,246 .^{101}$

2. Justice Blackmun. Justice Blackmun joined in the Court's opinion, but added a separate concurrence. Although acknowledging his "misgivings"102 as to the extent to which the legislative history supported the Court's result, Justice Blackmun found justification for the result in "additional considerations, practical and equitable, only partially perceived, if perceived at all, by the 88th Congress."103 Those considerations were the pressures on employers generated by administrative and judicial developments subsequent to the passage of Title VII-pressures that Justice Brennan had chosen to ignore. Quoting from Judge Wisdom's dissent, Justice Blackmun highlighted the dilemmas created by a literal reading of the Act:

The broad prohibition against discrimination places the employer and the union on ... a "high tightrope without a net beneath them." If Title VII is read literally, on the one hand they face liability for past discrimination against blacks, and

${ }^{97}$ See H.R. REP. No. 914, 88th Cong., 1st Sess. 18 (1963), quoted in Weber, 443 U.S. at 229 n.11 (Rehnquist, J., dissenting).

98 443 U.S. at 200,208 . The Justice, noting the absence of state action, suggested that Weber did not involve an alleged violation of the equal protection clause of the Constitution. This suggestion ignores the fact that a federal statute permitting a preference for one race but not another plainly involves governmental action. Nevertheless, a plaintiff who sues a private party, rather than the government, for action permitted by such a statute may be said to be challenging private action. See Flagg Bros., Inc. v. Brooks, 436 U.S. 149 (1978). This method of avoiding the constitutional question would be unavailable, however, if a unit of the federal or a state government, now subject to Title VII, adopted a Kaiser-type preference. Plainly, the Court's reliance on the state action point is at best a delaying action.

99 443 U.S. at 200.

100 Id. at 209 n.9.

103 See text and notes at notes 56-58 supra.

102443 U.S. at 209 (Blackmun, J., concurring).

${ }^{103}$ Id. (Blackmun, J., concurring). 
on the other they face liability to whites for any voluntary preferences adopted to mitigate the effects of prior discrimination against blacks. ${ }^{104}$

In order to protect employers and, more importantly, to promote their "voluntary compliance," Justice Blackmun would have adopted the approach urged in Weber by the government and Kaiser, although not the defendant-union, and approved by Judge Wisdom: "[E]mployers and unions who [have] committed 'arguable violations' of Title VII should be free to make reasonable responses without fear of liability to whites." 105 The Justice suggested that such a standard, although granting employers a privilege to engage in preferential hiring, was a sensible resolution of "a practical problem in the administration of Title VII."106 This emphasis on practical problems for employers arising from the pressures generated by regulation was, of course, not altogether consistent with the Court's emphasis on the "voluntary" nature of the preferences involved in Weber-an emphasis that Justice Blackmun did not question.

3. Justice Rehnquist. Justice Rehnquist's dissent ${ }^{107}$ concen-

104 Id. at 209-10 (Blackmun, J., concurring) (quoting Weber v. Kaiser Aluminum \& Chem. Corp., 563 F.2d 216, 230 (5th Cir. 1977) (Wisdom, J., dissenting)).

${ }^{205} 443$ U.S. at 211 (Blackmun, J., concurring). See also Brief for Petitioner Kaiser at 22, United Steelworkers v. Weber, 443 U.S. 193 (1979). The Steelworkers in Weber had rejected that position and had also urged that under Title VII, courts lacked authority to impose remedial group preferences. Brief for Petitioner United Steelworkers at 76-83, United Steelworkers v. Weber, 443 U.S. 193 (1979). If the Steelworkers' position had been adopted, a union with "power" could veto, or significantly affect, particular affirmative action programs, without fear of judicial requirements of "remedial" group quotas.

208443 U.S. at 211 (Blackmun, J., concurring). Justice Blackmun referred to the possibility of correction by Congress if the Court had "misperceived the political will." See id. at 216. Corrective legislation would, however, appear to involve a major, time consuming, and nationally divisive effort. That effort would, moreover, be complicated by the Court's decision, for there would be cries that corrective legislation would be turning the civil rights clock back. Justice Blackmun thus appears to have passed over the ways in which the framework for corrective legislation has been shaped by the Court's ostensibly judicial act. In any event, frequent resort to the Justice's argument in nonconstitutional cases would convert the Court into a council of legislative revision empowered to rewrite the mandate of Congress.

${ }^{107}$ The Chief Justice joined Justice Rehnquist's dissent but also filed his own separate dissent, stating that the majority had reached a result-the legalization of some quotas favorable to blacks-that he would support as a legislator considering a proposed amendment to Title VII. 443 U.S. at 216 (Burger, C.J., dissenting). His endorsement of the Court's end served to highlight his criticism of the Court's means, which he termed "intellectually dishonest." Id. at 219 (Burger, C.J., dissenting). Justice Rehnquist disavowed not only the Court's means but also its end, describing the Court's chosen device-the quota-as the "numerus clausus . . . a creator of castes, a two-edged sword that must demean one in order 
trated on the opinion of the majority and made only a brief reference to Justice Blackmun's emphasis on subsequent developments as justifying an arguable-violation approach. ${ }^{108}$

Complaining of the Court's Orwellian approach, ${ }^{100}$ Justice Rehnquist criticized the majority for eluding "clear statutory language, "uncontradicted' legislative history,"110 and its own uniform precedents. ${ }^{111}$ In his lengthy and vigorous opinion, he relentlessly documented each of those criticisms. To be sure, he conceded that the legislative debates focused primarily on compulsory quotas, rather than voluntary ones. ${ }^{112}$ But he pointed to numerous passages that stressed that employers were not to be permitted ${ }^{11 s}$ to discriminate in favor of either blacks or whites, and that racial quotas in employment-voluntary or involuntary-were to be forbidden. The power of his opinion is in part the power of repetition, and a summary cannot convey the force of his argument based on the legislative history.

Justice Rehnquist also effectively disposed of the argument, central to the Court's position, that the use of "require" in section 703(j) implied that "voluntary" racial preferences were not to be prohibited. His analysis was clear and direct: section 703(j) had been a response to criticism that the Act would be interpreted by courts and official agencies to require employers with racially unbalanced work forces to grant preferential treatment to minorities. ${ }^{114}$ Consequently, that section was added to prevent courts and agencies from imposing quotas. ${ }^{115}$ There had been at that time no need to deal with truly voluntary, as well as officially required, ra-

to prefer another." Id. at 254 (Rehnquist, J., dissenting).

${ }^{108}$ See id. at 225 n.6 (Rehnquist, J., dissenting). Justice Rehnquist dismissed this theory as apparently resting "on the conclusion that an employer is free to correct arguable discrimination against his black employees by adopting measures that he knows will discriminate against his white employees." Id. (emphasis in original).

${ }^{109}$ Id. at 219-21 (Rehnquist, J., dissenting).

${ }^{110}$ Id. at 222 (Rehnquist, J., dissenting) (quoting McDonald v. Santa Fe Trail Transp. Co., 427 U.S. 273, 280 (1976)). In McDonald, the Court concluded that "Title VII prohibits racial discrimination against the white petitioners [plaintiffs] in this case upon the same standards as would be applicable were they Negroes." 427 U.S. at 280.

111443 U.S. at 221 n.1 (Rehnquist, J., dissenting).

112 Id. at 244 (Rehnquist, J., dissenting).

113 See, e.g., id. at 232-43 (Rehnquist, J., dissenting). President Johnson's radio and television remarks upon signing the bill were to the same effect. While stressing that men were being denied the blessings of liberty because of their color, he said of the bill, "It does not give special treatment to any citizen." See II Public Papers of President Lyndon B. JoHNSON 445-46 (1965).

114433 U.S. at 244-46 (Rehnquist, J., dissenting).

115 Id. at 246 n.24 (Rehnquist, J., dissenting). 
cial preferences, for the language of Title VII, as proponents and opponents of the bill both understood, plainly banned voluntary quotas. ${ }^{116}$ And to bar officials from compelling action otherwise incompatible with clear statutory provisions and purposes was not to authorize equally incompatible private action..$^{117}$

Justice Rehnquist noted the ironic elements of the majority opinions. He pointed first to the Court's labeling of the Kaiser plan as "voluntary" even though it had been induced by official pressure on Kaiser from government agencies enforcing Executive Order $11,246,{ }^{118}$ and then to the Court's upholding that plan by invoking section $703(j)$, which had been designed to insulate employers against government pressures for quotas. By this tour de force the Court permitted the government to do exactly what opponents of the bill said the government would do, what the proponents said section 703(a) forbade, and what section $703(j)$ forbade again in an "excess" of caution. ${ }^{119}$

Justice Rehnquist added the final blow by pointing to section 703(i) of Title VII, ${ }^{120}$ which expressly permits firms on or near Indian reservations to grant publicly announced preferences for Indians living close by. ${ }^{121}$ Naturally, the Justice suggested that the Indian-preference provision showed Congress knew how to authorize preferences and would have used more exact language had it intended to except all voluntary preferences in favor of blacks from the blanket prohibition of racial discrimination. ${ }^{122}$

It is worth noting that Justice Rehnquist's textual and historical analysis is wholly compatible with the statutory purpose identified by the majority-to help blacks get jobs. Under the statute that end, however, was to be advanced by a particular means: by incorporating into law the equal opportunity that had for so long been denied blacks. It was clear in 1964, as it is today, that assuring such opportunity would help blacks enter the economic main-

116 Id. at 245 (Rehnquist, J., dissenting).

${ }^{117}$ Section 706(g) of Title VII carefully limits judicial authority for court-ordered "affirmative action" even when an employer or union has been found guilty of intentional discrimination. See text and notes at notes 137-153 infra. Those careful limitations run counter to the conclusion that Congress authorized private entities to grant race-conscious remedies in order to alleviate the effects of societal discrimination or to respond to "arguable discrimination" of their own.

118443 U.S. at 246 (Rehnquist, J., dissenting).

219 Id. (Rehnquist, J., dissenting). See also M. Sovern, supra note 95, at 70.

12042 U.S.C. $\$ 2000 \mathrm{e}-2(\mathrm{i})(1976)$.

121443 U.S. at 253 (Rehnquist, J., dissenting).

${ }^{122}$ Id. (Rehnquist, J., dissenting). 
stream. At that time, the pressing problem was not how to secure or to validate preferences in employment for blacks but how to secure for them equal opportunity -an opportunity to function on the basis of individual qualification or "merit," free from group prejudice or stereotyping. ${ }^{123}$

In this connection, it is worth recalling that for over a generation successive efforts to enact federal legislation designed to protect blacks, among others, against such employment discrimination had failed. ${ }^{124}$ It was only after the extraordinary events of the early 1960s, including the assassination of President Kennedy, that the necessary consensus for successful action against such discrimination at last emerged. The history of prior failures, coupled with the course of debate in 1964, made it clear that federal legislation ensuring equal opportunity for blacks probably could not have been enacted then if whites had not been promised and granted the same protection.

Furthermore, a sweeping antidiscrimination principle encompassing all races had deep moral roots, independent of the legislative history of the 1964 Act; equal opportunity for individuals and the irrelevance of their membership in particular racial groups had been a classic but unrealized goal of American society. To be sure, equal opportunity, without concern for unequal conditions, could be an idle ritual. But, as sympathetic commentators on Title VII stressed soon after its enactment, ${ }^{125}$ the attack on unequal conditions was not to be based on race or to involve selective employment discrimination against "innocent whites." Instead, that attack was to be based on need or disadvantage ${ }^{126}$ - a criterion that cut across racial lines and that was a better measure of inequality of condition and less troublesome-morally and politically-than race.

\section{B. The Arguable-Violation Approach}

Justice Blackmun, in his concurrence, conceded that Congress, when it enacted Title VII, "probably thought" that the statutory principle of nondiscrimination "would apply to blacks and whites

${ }^{123}$ See M. SOVERN, supra note 95, at 211.

124 See Meltzer, The National Labor Relations Act and Racial Discrimination: The More Remedies, the Better?, 42 U. CH. L. REv. 1, 12-13 (1974).

${ }^{125}$ See, e.g., M. Sovern, supra note 95, at 211-12.

126 Id. 
alike."127 After this candid acknowledgement that the Court was engaging in judicial nullification, the Justice set forth his justifications. They cast light on the entire course of decisions under Title VII as well as on the Court's approach in Weber. They also raise formidable questions as to the role of the Court and the limits of adjudication. Accordingly, Justice Blackmun's reasons, although he spoke only for himself, invite special attention.

As we have seen, his primary justification for excluding whites from the protection of the statutory nondiscrimination principle was to advance "voluntary compliance" with that principle as it applied to blacks. ${ }^{128}$ By allowing employers who had committed arguable violations of Title VII to engage in preferential hiring, the Court would enable those employers to redress (arguable) discrimination without fear of incurring liability to whites. In reworking and limiting the broad color-free standard of the Act he would not, however, have gone beyond the implications of that justification. $\mathrm{He}$ accordingly expressed concern that the Court, by allowing preferential hiring even in the absence of arguable violations, had encroached excessively on the color-blind standard of Title VII; ${ }^{129}$ the majority's approach would abrogate the statutory standard even where the employer was not on a "high tightrope without a net."130

The Justice advanced two principal reasons for overcoming his concerns. First, given the significance of statistical imbalance in Title VII litigation, the Court's approach and his would not, in practice, be significantly different. ${ }^{131}$ The standard for an arguable violation would have had to be set low enough so that it could be met without an employer's admitting a violation of Title VII. ${ }^{132}$ Furthermore, proof of an actual violation by the employer should not be required in cases like Weber as a condition for upholding racial preferences, for neither party in Weber had had an incentive to establish such a violation, and EEOC intervention in all such cases would not be feasible. ${ }^{133}$ In short, the Justice acknowledged

127443 U.S. at 213 (Blackmun, J., concurring). See also id. at 209.

${ }^{128}$ Id. at 209-11 (Blackmun, J., concurring).

${ }^{129} \mathrm{Id}$. at 212-13 (Blackmun, J., concurring).

${ }^{130}$ Id. (Blackmun, J., concurring).

131 Id. at 213 (Blackmun, J., concurring).

${ }^{132}$ Id. at 214 (Blackmun, J., concurring).

${ }^{133}$ Id. at 213-14 (Blackmun, J., concurring). Counsel for Brian Weber had kept the EEOC advised of the litigation from its inception. Brief for Respondent Weber at 22, United Steelworkers v. Weber, 443 U.S. 193 (1979). Even though the EEOC cannot inter- 
that the arguable-violation standard would be satisfied by proof of a statistical imbalance between the proportion of minorities in a given job category and the proportion of minorities in the relevant labor market-as would, of course, the majority's standard.194 Hence, questions about the qualifications of the minorities in that market and about whether the statistical disparity resulted from pre-Act or societal discrimination would not have to be considered. The emphasis, as the Justice put it, would be on "arguable" rather than on "violation."

The Justice also found "strong considerations of equity" supporting an interpretation of Title VII that would permit private affirmative action to reach pre-Act employment discrimination, as well as the effects of societal discrimination. ${ }^{136}$

1. Equitable Considerations: The Nature of the Remedy. The Justice did not pinpoint the equitable considerations that he considered pertinent. Nor did he deal with elements in the case that suggested that it was Brian Weber who could have made an appeal to equity ${ }^{137}$ even if Kaiser had been guilty of arguable or actual offenses under Title VII.

The crux of Weber's equitable claim was that there was no relationship between those injured by Kaiser's (arguable) offenses and those benefited by the remedy adopted by Kaiser and the Steelworkers. In short, the remedy devised by Kaiser and the Steelworkers did not fit the wrong. Thus, to take a concrete case, let us assume that Kaiser's discrimination had consisted of its prior requirement of experience for craft employment-a requirement that excluded a disproportionately high number of blacks and that might not have met the business necessity test. ${ }^{138}$ Kaiser and the Steelworkers would have been wholly justified in terminating that requirement and in granting back pay to blacks who showed that they had been adversely affected by it. Kaiser might even have been justified in granting make-whole restorative senior-

vene in "every case," that disability would not explain its abstention in Weber-a conspicuously important case. In any event, when litigants appear to lack pertinent incentives, a trial court could remedy that defect by appointing a litigating amicus, among other expedients.

134443 U.S. at 214 (Blackmun, J., concurring).

${ }^{133}$ Id. at 213 (Blackmun, J., concurring).

${ }^{136}$ Id. at 214-15 (Blackmun, J., concurring). Indeed, adding insult to injury, the Justice suggested that Brian Weber's attack on the Kaiser plan seemed "unfair," id.-a suggestion that seems especially puzzling, given the result in Bakke.

137 See Cohen, Why Racial Preference is Illegal and Immoral, Commentary, June 1979, at 40,44 .

${ }^{338}$ See text and notes at notes 29-31 supra. 
ity to individual victims, at the expense of black or white employees who had benefited, however innocently, from the prior discrimination.

Such individuated remedies, however, were not at issue in Weber, for there was absolutely no evidence that the blacks who benefited from Kaiser's preferential program had been victims of prior discrimination. Even within the terms of Justice Blackmun's formulation, it is difficult to see the basis for characterizing as "reasonable" a program of self-correction that involves such a manifestly bad fit between victims of the wrong and beneficiaries of the remedy.

The difficulties involved are sharpened by the substantial doubts that existed prior to Weber that a court-even after finding discrimination by Kaiser-would have been authorized to order such an ill-fitting remedy. It is true, as already indicated, that many lower courts, after finding a violation of Title VII or the Constitution, have granted such relief. ${ }^{139}$ But the Supreme Court has not squarely approved that position, and considerable doubt as to its propriety arises from the language ${ }^{140}$ and legislative history of the Act. ${ }^{141}$

In exploring that issue, it is, of course, necessary to distinguish the group remedial quota from the "rightful place" remedy for individuals. The latter remedy is wholly consistent with the focus of the statute on individuals and was approved in Franks $v$. Bowman Transportation Co., ${ }^{142}$ in which the Supreme Court upheld classbased seniority relief for identifiable victims of employment discrimination, retroactive to the date of the application for employment. In approving such relief, under section 706(g) of the Act, ${ }^{143}$ the Court emphasized that the "central 'make-whole" " principle of Title VII justified whatever adverse effect such a remedy might have on other employees; ${ }^{144}$ furthermore, a similar practice was standard under the National Labor Relations Act ${ }^{145}$ ("NLRA") - the model for the remedial sections of Title VII. ${ }^{148}$

It is worth recalling that, in Bowman, Justice Powell dissented

\footnotetext{
139 See cases cited notes 46-47 supra.

140 For the text of section 706(g), see note 153 infra.

11 See note 52 supra.

142424 U.S. 747 (1976).

143 Id. at 779.

144 Id. at 774.

14829 U.S.C. $\$ \S 151-169$ (1976).

14624 U.S. at $769,774$.
} 
from the Court's approach to make-whole remedies, urging that it virtually commanded lower courts to grant such relief without weighing the equitable claims of "innocent incumbents."147 Plainly, these equities are even stronger when an employer's preferences impose costs on innocent employees and grant benefits to individuals who have not been the victims of discrimination. ${ }^{148}$ These implications of Justice Powell's dissent are reinforced by the decision of the Court, written by Justice Stewart, in International Brotherhood of Teamsters $v$. United States. ${ }^{149}$ Even in the face of proof of a pattern and practice of discrimination by the employer, the Court in Teamsters ruled that the offending employer could avoid liability to an individual applicant by showing that the applicant had been rejected for other than racial reasons. ${ }^{160}$

Another impediment to group remedies is the Court's approach in H.K. Porter Co. v. NLRB, ${ }^{151}$ where it concluded that the remedial provisions of the NLRA are limited by the substantive principles of that Act. The Court stressed that under those principles, collective bargaining agreements are to be worked out by the parties and not to be imposed by government. ${ }^{162}$ Accordingly, the

147 Id. at 795 (Powell, J., concurring in part and dissenting in part). See note 43 supra.

${ }^{148}$ Cohen, supra note 137. In Bakke, Justice Powell referred to decisions by courts of appeals that "fashioned various types of racial preferences as remedies for constitutional or statutory violations resulting in identified, race-based injuries to individuals held entitled to the preference." 438 U.S. at 301 (emphasis added). Nevertheless, the cases he cited had approved preferences for members of particular racial groups even though the individual beneficiaries had not been identified as victims of the offenses involved. In Bridgeport Guardians, Inc. v. Bridgeport Civil Serv. Comm'n, 482 F.2d 1333 (2d Cir. 1973), the court established quotas as high as 3:1 (black:white) in order to "eradicate the effects of past discriminatory practices," id. at 1340. The court did not, however, specify which "effects" the decree corrected, nor did it make any effort to grant the benefit of "remedial" quotas to actual victims of discrimination. There was a similar lack of specificity in the other case relied on by the Justice, Carter v. Gallagher, 452 F.2d 315 (8th Cir. 1971) (en banc), cert. denied, 406 U.S. 950 (1972). The court there did, however, identify as a "present effect" the employer's bad reputation in the minority community. Id. at 331 .

149431 U.S. 324 (1977). In Bakke, Justice Stewart, disagreeing with Justice Brennan, had joined in Justice Stevens's opinion, declaring that Title VI bans the use of race-conscious standards by the institutions that it covers. Regents of the Univ. of Cal. v. Bakke, 438 U.S. 265, 414 (Stevens, J., concurring in the judgment in part and dissenting in part). In Weber, Justice Stewart joined Justice Brennan's opinion for the Court despite its obvious tensions with the opinions by Justices Stevens and Powell in Bakke. Justice Stewart's joining the Court in Weber may have been linked with the Court's careful reservation of the question regarding judicial authority to order "remedial" quotas. 443 U.S. at 211.

${ }^{150}$ See 431 U.S. at 362 . See also text and note at note 155 infra.

181397 U.S. 99 (1970).

132 Id. at 107-08. But cf. NLRB v. Gissel Packing Co., 395 U.S. 575, 610-16 (1969) (upholding bargaining order as a remedy where employer's unfair labor practices found to have spoiled chance for fair election). 
Court held that it was beyond the authority of the National Labor Relations Board to remedy an employer's refusal to bargain about a check-off provision by requiring him to include such a provision in his collective agreement. A similar approach under Title VII would require courts to take account of the language and purpose of section 703(j) - which bars imposition of quotas - when delineating the scope of section $706(\mathrm{~g}),{ }^{163}$ the remedial provision of the Act. Such an approach would permit preferences under Title VII only when necessary to make individual victims, as distinguished from racial groups, whole. ${ }^{154}$

There would be obvious anomalies in an interpretation of Title VII that denied courts authority to require that proven violators grant group preferences while permitting employers to grant "voluntary" preferences, despite similar adverse consequences for innocent individuals in both situations. Courts in general could be expected to give more careful and detached consideration to the competing interests at stake ${ }^{165}$ than employers seeking protection from official and private pressures for "quotification" of their work forces.

${ }^{163}$ Section 706(g) of Title VII, 42 U.S.C. $\S 2000 \mathrm{e}-5(\mathrm{~g})(1976)$, provides in part:

If the court finds that the respondent has intentionally engaged in or is intentionally engaging in an unlawful employment practice charged in the complaint, the court may enjoin the respondent from engaging in such unlawful employment practice, and order such affirmative action as may be appropriate, which may include, but is not limited to, reinstatement or hiring of employees, with or without back pay (payable by the employer, employment agency, or labor organization, as the case may be, responsible for the unlawful employment practice), or any other equitable relief as the court deems appropriate. . . . No order of the court shall require the admission or reinstatement of an individual as a member of a union, or the hiring, reinstatement, or promotion of an individual as an employee, or the payment to him of any back pay, if such individual was refused admission, suspended, or expelled, or was refused employment or advancement or was suspended or discharged for any reason other than discrimination on account of race, color, religion, sex, or national origin . . . .

This section, especially if read in conjunction with section 703(j), 42 U.S.C. \$ 2000e-2(j) (1976), suggests that preferences are allowed only to make identifiable victims of discrimination whole.

In Weber, Justice Brennan, without referring to precedents under the NLRA, stated that "remedies for substantive violations are governed by $\S 706(\mathrm{~g})$ " while also stating that "[s]ection 703(j) speaks to substantive liability under Title VII." 443 U.S. at 205 n.5.

${ }^{156}$ Indeed, the NLRB, when it finds that an employer, in order to avert unionization, has discriminated against union members in hiring, orders affirmative action in the form of back pay and reinstatement to identified victims of such discrimination. The Board has not, to my knowledge, directed such an employer in future hiring to give preferential treatment to union members who were not victims of the violation.

${ }^{155}$ The district court in Weber stressed those considerations in concluding that courts, but not private parties, were authorized to establish "quota systems where appropriate." 415 F. Supp. at 767-68. 
We need not pursue such anomalies here; they are obviously part and parcel of the Court's emphasis in Weber on voluntarism and the avoidance of overregulation. It is enough for our purposes to observe that Justice Blackmun seemed to ignore that the Court's opinion, which he joined, carefully reserved the question of the propriety under Title VII of remedial group preferences. ${ }^{158}$ Thus, he emphasized that the Weber litigants lacked an incentive to establish Kaiser's prior discrimination. ${ }^{167}$ But that point would be important only if a judicial finding of such discrimination would provide authority for a remedial decree mandating a program such as Kaiser's. If courts lack such authority, the issue is simply whether employers not shown to have violated the Act should have greater authority to establish group preferences than courts dealing with proven violators.

2. "Compliance" Through "Violation." In any event, Justice Blackmun's emphasis on "arguable violations" and "voluntary" compliance suffers from an obvious circularity. The arguable-violation approach is needed only if Title VII in general bars all employment discrimination-in favor of or against blacks. But if the statute is read in that way, it is not clear (as Justice Rehnquist noted ${ }^{158}$ ) why remedying arguable discrimination against members of one group should justify actual and undeniable discrimination against members of another group. In other words, even though it is conceded that "voluntary compliance" is more important under this statute than generally, the characterization of conduct as "voluntary" does not answer the question whether it constitutes compliance. All of Justice Blackmun's subsidiary arguments seem to beg that basic question and convert a broad antidiscrimination principle into a question of whose ox is being gored. ${ }^{188}$

To notice the logical defects in the arguable-discrimination approach is not to downplay the employer's dilemma generated by developments under Title VII and Executive Order 11,246. Nevertheless, it is important that one keep in mind that the statute was designed to regulate employers and to protect employees. If a

188443 U.S. at 200.

${ }^{137}$ Id. at 213-14 (Blackmun, J., concurring). Contrary to the Justice's assumption, in some situations the potential liability (pre-Weber) from "reverse discrimination" would be so much greater than the liabilities from past discrimination against blacks that the incentive to admit past discrimination would have existed-if it avoided the first kind of liability.

${ }^{158} \mathrm{Id}$. at $225 \mathrm{n} .6$ (Rehnquist, J., dissenting).

158 See A. BICKEL, supra note 7, at 133, quoted in Regents of the Univ. of Cal. v. Bakke, 438 U.S. 265, 295 n.35 (1978) (opinion of Powell, J.). 
choice must be made between a quieter life (or government contracts) for employers and the abrogation of statutory protection for some classes of employees, nothing in the statute suggests that it is the employees' interests that should be sacrificed. ${ }^{160}$

It is, moreover, likely that the safety net provided by Weber or the arguable-violation theory will be less secure than Justice Blackmun implied. ${ }^{161}$ Thus, if a quota fixed for blacks should be challenged by Hispanics, Asiatics or white women, it would be far from clear that the one-to-one, black-white quota would stand up in a labor market where blacks constitute $39 \%$ of the workers. On the other hand, if the employer grants the blacks $39 \%$ of the preferred jobs and the blacks urge that that quota is inadequate redress for "past discrimination," the voluntary preference may not forestall litigation over both the existence of past discrimination and the proper remedy for its identified victims. In short, Weber may change the parameters for pressure by the Office of Federal Contract Compliance ("OFCC") and civil rights groups, rather than substantially curb litigation about the responses to such pressures. Moreover, to the extent that it does curb such litigation, it may well do so only by reducing employers' incentives to resist pressures in favor of granting some favored minority (or minorities) a preference that is excessive in relation to the percentage of that minority in some labor markets.

In any event, "voluntary" preferences for groups cannot wipe out liability for past violations to identifiable individual victims. ${ }^{162}$ To be sure, such preferences may divert attention from past discrimination against identifiable victims and may thereby reduce litigation over their claims. But that reduction would presumably be at the expense of adequate relief for such victims. Indeed, Justice Blackmun intimated that it is desirable that voluntary quotas confuse things in this way. ${ }^{163}$ It is not clear, however, why the

${ }^{160}$ An employer's difficulties are less acute in a case such as Weber, in which the relief requested is not damages for past "reverse" discrimination but an injunction against its continuation. It is true that such an injunction might prevent the employer from achieving the ethnic proportionalities that might in turn encourage litigation by or on behalf of blacks. But an injunction granted to a Brian Weber would presumably be given evidentiary weight in a later action against the employer. $C f$. Alexander v. Gardner-Denver Co., 415 U.S. 36, 60 \& $n .21$ (1974) (arbitral decision).

161 See text at notes 191-192 infra.

${ }^{162}$ See Furnco Constr. Corp. v. Waters, 438 U.S. 567, 584 (1978) (Marshall, J., joined by Brennan, J., concurring in part and dissenting in part).

163443 U:S. at 211 (Blackmun, J., concurring) ("[Kaiser] is able to avoid identifying victims of past discrimination, and so avoids claims for back pay that would inevitably fol- 
Court should prefer a scheme that decreases the likelihood that individual victims will seek relief.

3. "Additional Considerations, Practical and Equitable." It is now useful to look more closely at Justice Blackmun's general suggestion that "additional considerations, practical and equitable, only partially perceived, if perceived at all, by the 88th Congress," 164 support the Court's conclusion. It is worthy of emphasis that these considerations (even assuming that they were not perceived by Congress) are not changes in societal circumstances; on the contrary, they consist of the judicial decisions and executive practices that generated pressures for racial quotas despite resultant tensions with the statutory language and history. These regulatory developments presented the Court in Weber with a manifestly difficult problem. One response was to accept the idea-advanced by Justice Blackmun - that the language and original purpose of the Act had been outdistanced by events. The difficulty with that approach is plain. The superseding events were, as already indicated, not external to regulation but rather were decisions by the judiciary and the executive that ran counter to the political and ethical bargain struck by the 88th Congress. Thus the inadequate perceptions imputed to Congress consist principally of its failure to realize that courts would so transform a broad antidiscrimination principle as to encourage employment decisions that discriminate against white males. ${ }^{165}$ To invoke such developments as justification for reworking the central provision of the

low a response limited to such victims").

The pertinent difficulties are illustrated in the following situation: After the Civil Rights Act became effective, an employer may have engaged in discrimination against two black employees. In order to bolster his legal defenses against a lawsuit by them, he grants preferences to two other blacks, who were not affected by the employer's wrong, at the expense of two whites, who were not benefited thereby. It is difficult to see why it is equitable for voluntary action to impede a remedy for actual victims of discrimination, while granting a preference to other blacks at the expense of whites who did not benefit from the prior discrimination. When, as in Weber, the employer has not been found guilty of or acknowledged actual discrimination against individual blacks, the equity of voluntary racial preferences surely does not become more appealing.

${ }_{104} 443$ U.S. at 209 (Blackmun, J., concurring).

${ }_{185}$ Presumably, Congress (or some of its members) underestimated the difficulty of ending various employment practices that were not explicitly or deliberately discriminatory but that impeded access of blacks to jobs. Thus, in addition to standardized tests, employment criteria such as educational prerequisites, arrest records, garnishments, and interviews might have an adverse impact on blacks, while lacking strong job-relatedness. Whatever the congressional perceptions about such difficulties, the debates made it clear that quotas were an impermissible method of dealing with impediments to equal employment opportunity. See note 52 supra. 
statute involves a striking reversal of roles. It demonstrates a failure to recognize whose perceptions-the judiciary's or Congress's-should be respected concerning a statute that was enacted after debates that focused on the specific type of problem before the Court.

Indeed, the Weber Court had another, albeit perhaps more difficult alternative: to honor the language of the statute and the political and ethical consensus it embodied. If doing so in a case such as Weber placed innocent employers in intolerable situations, the Court could reexamine and, if need be, revise its earlier precedents. ${ }^{186}$ To be sure, such an approach would increase the risk that an employer's covert discrimination might go undetected. This risk of underenforcement of Title VII is a serious one. But it is not to denigrate the statutory purposes or to be complacent about underenforcement to observe that the risk of imperfect enforcement is endemic to all regulation and cannot be curtailed significantly without important costs to the integrity of our enforcement processes. In the case of Title VII, that risk could be reduced with respect to blacks by choosing to uphold clear and unequivocal discrimination against whites-as was done in Weber. That choice, however, validates explicit racial quotas as a part of our legal and symbolic code and ignores the mandate reflected in the language, the history, and the social matrix of the Act-a mandate for nondiscriminatory treatment for whites as well as blacks.

The Court's approach cannot be justified on the ground that the change made by Weber is only a response to a minor hitch, unforeseen by Congress, that often emerges as a statute is administered. That change goes to the roots of the bargain struck by the 88th Congress, and to the roots of our color-blind aspiration. Weber is, in fact, an important step in the transformation of the classic and widely supported liberal ideal of equal opportunity for individuals into a new program of equal outcomes for groups that is both more divisive than the older ideal and fundamentally inconsistent with it.

\section{Affirmative Action and the Court's Role}

The meanings of "equality" and of "equal opportunity" and

\footnotetext{
${ }^{186}$ For suggestions regarding corrective action, see Glazer, Issues on Availability, in Perspectives on Avallability 217 (1977); Lerner, Employment Discrimination: Adverse Impact, Validity, and Equality, 1979 SuP. CT. Rev. 17.
} 
their relationship to equity and efficiency have been the subjects of a vast literature ${ }^{167}$ that cannot and need not be reviewed here. But what merits emphasis is that choosing between competing values underlying those concepts-under the guise of statutory construction-appears to have strained the Court's institutional competence. The Court's opinion does not even notice some basic and troubling questions relevant to a disinterested and informed choice. One need not romanticize the process of legislative investigation or legislative decision to recognize that litigation is as illsuited for informing the Court about the pertinent questions as the Court is for resolving them. In any event, in illustrating questions neglected by the Court, I will point to those pivotal to the Court's stated objective-helping blacks, and especially unemployed blacks, ${ }^{168}$ into the mainstream of our economy.

Is official pressure for affirmative action a substantial factor in the flight of business from the centers of black population, as employers attempt to avoid pressure for quota hiring ${ }^{169}$ As a conse-

${ }^{187}$ For a discussion of some of the literature, see Simons, Book Review, $77 \mathrm{Mrch}$. L. REv. 513 (1979).

${ }^{183}$ See 443 U.S. at 204 n.4 (indicating that ratio of nonwhite unemployment to white unemployment had increased from 1962 to 1978). For a discussion of the diverse opinions regarding the effects of government antidiscrimination programs on wages and unemployment of black workers, see Butler \& Heckman, The Government's Impact on the Labor Market Status of Black Americans: A Critical Review, in EQual Rights AND Industrial Relations 235, 265-67 (1977). See also J. Smith \& F. Welch, Race Difrerences in EarNings: A Survey and New Evidence (Rand Report No. R-2295-NSF 1978); W. Wilson, The Declining Significance of Race 88-121 (1978).

${ }^{160}$ For indications that affirmative action requirements are a factor in the location of new plants in areas with few minority residents, see N.Y. Times, Mar. 19, 1978, $\$ 1$, at 18 col. 1. See also Kaplan, Equal Justice in an Unequal World: Equality for the Negro-The Problem of Special Treatment, 61 Nw. U.L. Rev. 363, 373 (1966) (recognizing the force of this consideration but noting that it can be overdone).

The EEOC has indeed challenged relocation from urban to suburban locations. E.g., EEOC v. North Hills Passavant Hosp., 466 F. Supp. 783, 787 (W.D. Pa. 1979) (charge dismissed on the ground that move prompted by self-preservation rather than by "race"). See also Note, Suburban Relocation of Urban Employers-A Contemporary Problem in Employment Discrimination, 62 Iowa L. REv. 427 (1976). Industrial flight from concentrations of minority workers may frustrate the underlying purposes of Title VII. But the location or relocation of a plant depends on many factors, including perhaps the desire to avoid "underutilization" of minorities in a work force. To apply Title VII and the disparate impact and business necessity test to plant relocation would confer on courts sweeping powers whose far-reaching implications for the economy need not be explored here. Cf. Local 57, Int'l Ladies Garment Workers Union v. NLRB (Garwin Corp.), 374 F.2d 295 (D.C. Cir.) (runaway plant as violation of NLRA), cert. denied, 387 U.S. 942 (1967). See also NLRB v. Rapid Bindery, Inc., 293 F.2d 170 (2d Cir. 1961). Plainly, such judicial control would involve the sharpest tensions with the avoidance of overregulation found to be an important congressional purpose by the Court in Weber. See text and note at note 91 infra. 
quence, are the most disadvantaged blacks being hurt by regulation designed to help them? Will those hoping to cultivate the grievances of whites in order to promote bigotry now be able to march under an honorable banner-equal opportunity for all? Will the fallout from Weber intensify racial politics and further polarize our work forces and our communities? ${ }^{170}$ Will it obstruct important job training across racial lines-the spontaneous on-the-job instruction of one worker by another? Will Weber and the centrifugal tendencies that it promotes create further obstacles to legislative action necessary for programs designed to help all the disadvantaged, black and white? Will quota hiring result in significant inefficiencies-thereby retarding economic growth, to the particular disadvantage of minorities? And, on a different point, can a shift from individual to group "rights" be stabilized anywhere short of a transformation of the basic values of our society and our political, legal, and economic institutions-short of a virtually "quotified society"?

These illustrative questions are not only legislative and political but also, as already indicated, critical to the achievement of the purpose the Court imputed to Congress. There is no indication that the Court considered them. On the other hand, the Court, in disposing of Weber without appropriate regard for Congress's mandate, risks its future capacity to discharge an important judicial function, that of satisfying a deeply felt need for trustworthy neutrals, as Professor Dawson put it. ${ }^{171}$

The liberties taken by the Court contributed to Weber's failing a classic test for a Supreme Court opinion: that it give reasonable explanations transcending the result in the case being decided. ${ }^{172}$ Although Weber affects virtually the entire work force, it does not provide coherent guidance to private lawyers who must give day-to-day advice, to government officials with enforcement responsibilities, or to judges who must deal with a flood of litigation. The Court, as we have seen, ${ }^{173}$ emphasized that it was deciding only the case before it. This strategy of ostensible postponement adds still another ironic twist to a decision motivated in part by arguments that something had to be done to alleviate the un-

170 See generally Perry, Modern Equal Protection: A Conceptualization and Appraisal, 79 Colum. L. Rev. 1023, 1044-45 (1979); Van Alstyne, Rites of Passage: Race, the Supreme Court, and the Constitution, 46 U. CHI. L. Rev. 775, "805-08 (1979).

${ }^{171}$ J. Dawson, The Oracles of the Law xui (1968).

172 See id. at xi-xii.

173 See text and note at note 98 supra. 
certainties resulting from ambivalent regulations.

\section{The Reach of the Court's Opinions}

The narrowness of the Court's opinion may, despite Justice Brennan's efforts, turn out to be more apparent than real. The distinctive elements of Weber stressed by the Court are in the main so unrelated to its basic argument that, if the Court persists in its fundamental position, those elements are unlikely to have any importance. Furthermore, they are in general so ill-defined that they fail to provide a basis for a limiting rule. In order to develop these points, it is appropriate to review those elements of the Kaiser plan emphasized by the Court.

First, even as to blacks, quotas in Weber were validated only with respect to "traditionally segregated job categories"174 in the private sector. Since the Court did not delineate those categories, its opinion leaves unanswered many questions: Do jobs once "traditionally segregated" remain so and, if so, for how long after black representation has markedly increased? Does the Court's emphasis mean that quotas may not be established for relatively new job categories, such as computer programmers, if such categories have not involved any racial exclusion in the past but at present involve a racial imbalance? Does "traditionally segregated" mean anything more than current racial imbalance? ${ }^{175}$ How are job categories to be defined for these purposes? If, for example, the relevant rubric were "white collar" jobs, computer programmers might easily fit under a "traditionally segregated" category; the result might be different if the rubric were "computer programmers." And is traditional segregation to be determined on a national, regional, or local basis? In any event, if "traditionally segregated" were narrowly construed, the option that Weber grants to employers might not extend to relatively new and growing sectors of the economy.

174443 U.S. at 209.

178 In connection with this question, it is worth noting that the Court expressly took judicial notice of numerous decisions rendered after the enactment of Title VII that had rested on findings of deliberate racial exclusion from crafts. See id. at 198 n.1. These findings primarily involved the construction trades. The Court, moreover, also referred to general studies of pre-Act discrimination. The Court did not, however, pinpoint the extent to which industrial unions (as distinguished from craft unions) and employers had engaged in racial discrimination. To be sure, discrimination in construction and in society presumably reduced the pool of skilled blacks available for factory jobs. But the Court's failure to consider possible differences in the construction and other industries, respectively, coupled with its indifference to the absence of demonstrated discrimination at Kaiser, contributes to the uncertainties spawned by its opinion. 
A similar limitation may be implicit in the Court's emphasis that Weber involved a private employer. For the public sector has in the last decade been the faster growing part of our economy. The Court's emphasis might be explained on the ground that governmental quotas would involve the state directly in racial discrimination, thereby raising troublesome constitutional questions. ${ }^{176}$ But Title VII now also applies to the public sector and does not by its terms draw a distinction between the validity of "voluntary" quotas developed by private and public employers, respectively. Accordingly, it is likely that the Court will soon be faced with a constitutional question arising from the claim that Title VII permits "voluntary" quotas by public bodies, qua employers. ${ }^{177}$

Another source of uncertainty is implicit in the Court's reiteration that the Kaiser program had been collectively bargained. ${ }^{178}$ Judge Wisdom, dissenting below-but not the Supreme Court-sought to explain why that consideration was entitled to weight. ${ }^{179} \mathrm{He}$ suggested that the duty of fair representation may reenforce internal restraints on a union's willingness to agree to racial preferences adverse to a majority, or to many union constituents. It is difficult, however, to discern a basis for giving any legal significance to that point. If Title VII bars all employment discrimination by an employer, the union, by agreeing to a discriminatory standard, is guilty of a breach of the duty of fair representation-at least if it has a specific discriminatory intent. ${ }^{180}$ The participating union may, moreover, also be guilty of a violation of Title VII. The fact that internal union politics might limit the extent of its breach of duty or its statutory violation would not change the fact that a breach by the union and a statutory violation by the employer and possibly by the union had occurred. On

128 The divergent opinions in the Bakke case indicate how deeply divided the Court is on the question of the constitutionality of preferential treatment. See notes 96, 98 supra.

177 At least one federal court, relying on Weber without discussing its limitations, has held lawful under Title VII a public employer's use of an allegedly remedial quota for blacks. Detroit Police Officer's Ass'n v. Young, 20 Fair Empl. Prac. Cas. 1728, 1739-40 (6th Cir. 1979). See also Price v. Civil Serv. Comm'n, 604 P.2d 1365, 161 Cal. Rptr. 475 (1980).

178443 U.S. at $197-99$.

179563 F.2d at 232-33 (Wisdom, J., dissenting).

${ }^{180}$ A union's proposal or acceptance of a discriminatory contract provision may violate Title VII despite the union's good faith and reasonableness, whereas a breach of the duty of fair representation generally presupposes bad faith and arbitrary action on the union's part. See generally Finkin, The Limits of Majority Rule, 64 Mins. L. REv. 183, 213-15 (1980); Note, Union Liability for Employer Discrimination, 93 HARv. L. REv. 702, 703-05 \& passim (1980). Since the union has greater leeway under that duty, it is difficult to see its relevance in the Weber context. 
the other hand, if, notwithstanding Title VI, an employer is entitled to adopt "voluntary" programs of racial preference, it does not appear to be legally significant that a union might restrain the extent to which an employer exercises that right.. ${ }^{181}$

There are, moreover, aspects of a union's duty of fair representation that lend an air of perversity to suggestions that the existence of that duty should make it easier to uphold racial preferences. As Chief Justice Stone once observed, the duty is based on "a principle of general application that the exercise of a granted power to act in behalf of others involves the assumption towards them of a duty to exercise the power in their interest and behalf." ${ }_{182}$ That principle was, to be sure, articulated in response to discrimination against blacks within a bargaining unit. ${ }^{183}$ But it reflected a larger purpose to protect all individuals against arbitrary action by those who purport to exercise collective power on their behalf. ${ }^{184}$ To rely on the existence of that duty to justify collectively bargained discrimination, albeit against whites in a bargaining unit, is to ignore its basic function as a restraint on collective power. Finally, collective bargaining agreements cover less than $25 \%$ of the work force. If the Court's approach is sound, it would be bizarre to confine it to such a small part of the economy. ${ }^{185}$

The Court also seemed to attach some significance (1) to the fact that the disputed Kaiser program did not constitute an absolute bar to the admission of whites ${ }^{188}$ and (2) to its own finding

${ }^{181}$ The Steelworkers in Weber agreed to a $50 \%$ quota for blacks in the training program even though the blacks (relative qualifications aside) constituted at most $39 \%$ of the relevant labor force. A quota greater than statistical parity is difficult for the employer to justify, see text and notes at notes 187-190 infra, and even more so for the union, obliged as it is to balance fairly the competing interests of all members of the bargaining unit.

${ }^{182}$ Steele v. Louisville \& N.R.R., 323 U.S. 192, 202 (1944).

183 Id. at 196.

184 The labor movement in the United States is passing into a new phase. The struggle of the unions for recognition and rights to bargain, and of workmen for the right to join without interference, seems to be culminating in a victory for labor forces. We appear now to be entering the phase of struggle to reconcile the rights of individuals and minorities with the power of those who control collective bargaining groups.

Wallace Corp. v. NLRB, 323 U.S. 248, 271 (1944) (Jackson, J., dissenting).

185 Whatever importance ultimately attaches to a union's involvement in the negotiation of an affirmative action plan, the situation created by the Court's opinion may well result in heightening racial consciousness in labor-management relations. Thus, in organizing campaigns, Weber would provide a basis for an employer's arguing to white employees that a union's victory-at least if the union's leadership is predominantly white-might facilitate lawful reverse discrimination.

${ }^{288}$ The Court noted that the plan did not deprive the whites of preexisting rights, such as protection against layoffs based on seniority, but established new rights to training for 
that the plan was temporary, and "not intended to maintain racial balance, but simply to eliminate a manifest racial imbalance."18z Again, it is difficult to fit those factors into the Court's argument. Although whites were eligible for Kaiser's training program, the $50 \%$ of spaces allocated to blacks exceeded their ratio in the local labor force. Thus, even if one accepted the dubious premise that, absent discrimination, employment in particular plants (and their various departments) would reflect the ethnic ratio of the surrounding community, ${ }^{188}$ that premise would not help to uphold the Kaiser plan because the plan called for "overrepresentation" of blacks in the training program.

Plainly, the Kaiser plan was developed, not as a prophylactic against future discrimination by Kaiser, but as a catch-up remedy for past discrimination by society. ${ }^{180}$ If such a "voluntary" remedy is favored or tolerated as a way of helping blacks into the economic mainstream, why should the law restrain an employer who wishes to help blacks catch up even more quickly by reducing the ratio of

whites as well as blacks. 443 U.S. at 208. See also id. at 215 (Blackmun, J., concurring). To be sure, that factor mitigated the effect of the racial standard, but did not change its nature. Thus if senior blacks had been excluded from a training program solely because of their race, such exclusion would not be validated because it occurred under a program that established training opportunities previously unavailable to blacks as well as whites.

${ }^{187}$ Id. at 208. The Court, purporting to redeem pledges by Senator Humphrey and others in the legislative debates, rejected the suggestion that the plan was designed permanently to "maintain a racial balance." Id. at 207 n.7. Justice Rehnquist pointed, however, to testimony by Kaiser personnel that undermined the conclusion that the plan was "temporary," id. at 223 n.3 (Rehnquist, J., dissenting), and persuasively suggested that the maintain/achieve distinction is analytically indefensible, $i d$. at $240 \mathrm{n}$.19. In any event, the company estimated that even with the plan, black underrepresentation would continue for 30 years. Brief of Petitioner Kaiser at 52, United Steelworkers v. Weber, 443 U.S. 193 (1979). Cf. Price v. Civil Serv. Comm'n., 604 P.2d 1365, 1385 n.4, 161 Cal. Rptr. 475, 495 n.4 (1980) (Mosk, J., dissenting) ("This may give an impression of being a mere temporary expedient. But the French, with a cynicism born of experience, have an appropriate saying: 'rien ne dure comme le provisoire' (nothing lasts like the provisional).").

${ }^{188}$ In International Bhd. of Teamsters v. United States, 431 U.S. 324 (1977), the Court asserted that "it is ordinarily to be expected that nondiscriminatory hiring practices will in time result in a work force more or less representative of the racial and ethnic composition of the population" at large. Id. at 340 n.20. The Court's assumption (apart from its pliable qualification) is effectively challenged in Glazer, Issues on Availability, in Perspectives on AvaIlability, supra note 166, at 219. He argues that discrimination plays a small part in the occupational distribution of ethnic groups in the United States. See generally E. HuTcHiNSON, IMmigrants aNd TheIr ChILDREN, 1850-1950, at 273-78 (1956). In any event, the diffculties underlying the Court's assumption are suggested-impressionistically-by a recent story that " $80 \%$ of the nation's professional comedians [not further defined] are Jewish." TIME, Oct. 2, 1978, at 76, col. 1 .

${ }^{180}$ There was no suggestion below that a remedial quota was necessary to guard against any commitment to covert discrimination on the part of Kaiser. 
whites or barring them altogether until a given statistical goal for blacks is reached? Similarly, if an employer can lawfully establish a quota for blacks higher than their ratio in the local labor force, why should an employer who has achieved statistical parity in his own plant be barred from continuing his preference as a means of compensating for still unremedied "societal discrimination" elsewhere? As these questions make clear, there is no principled basis in the Court's opinion for upholding only those "voluntary" preferences that have the indicia of "moderation" stressed by the Court in Weber. ${ }^{190}$

The Court's emphasis on Congress's preoccupation in 1964 with the plight of blacks invites the question whether voluntary employment preferences may not favor Hispanics, white women, or members of other "protected groups" who are not black. Nevertheless, the Court's emphasis on voluntarism and on "traditionally segregated job categories," as well as Justice Blackmun's emphasis on safety nets for employers, could be invoked to validate some "voluntary" preferences designed to redress "underrepresentation" of nonblack "protected" groups. ${ }^{191}$

If voluntary preferences for nonblack groups are brought within Weber's rationale, a cluster of additional complexities will arise from charges that blacks are being excessively favored at the expense of Hispanics, women, or Vietnamese refugees-or from charges that run the other way. May an employer lawfully prefer blacks, male and female, to better qualified white females? ${ }^{192}$ Such a question would be complicated by adding members of other protected groups to women and blacks as candidates for preferences, and by presenting hypothetical numbers that would provide a

190 The Court also noted that Kaiser's program did not involve any layoffs of white employees. 443 U.S. at 208. No doubt that element made the plan more prudent and more palatable to the company and union and to white employees uninterested in the training program. But Title VII generally encompasses "discrimination" whether it involves layoffs or promotions, and it is, accordingly, difficult to relate the absence of layoffs to the language or purpose of the Act.

191 In Edmondson v. U.S. Steel Corp., [1979] 2 LAB. ReL. ReP. (BNA) (20 Fair Empl. Prac. Cas.) 1745 (N.D. Ala. Oct. 2, 1979), the court upheld a preferential program for women, citing Weber, without any discussion of the limitations in the Court's opinion.

192 An employer might adopt such a program for a variety of reasons: his conviction that blacks, because of the special consequences of slavery, were specially entitled to compensatory group preferences, or because of pressures by private civil rights groups and government agencies. On the other hand, male plaintiffs have challenged the legality of promotion quotas worked out with the New York City Human Rights Commission allegedly favoring less qualified women over male candidates. See N.Y. Times, Oct. 30, 1979, § B, at 1, col. 7. 
plausible basis for charges by blacks or other groups that they were being shortchanged. It is understandable that the Court in Weber did not rush to confront either of these difficulties, or the related difficulties of formulating and applying racial classifications. These problems are, however, likely further to balkanize the work force and to aggravate the uncertainties that already surround personnel decisions. ${ }^{193}$

The uncertainties mentioned above, although they may limit the use of "voluntary" preferences, will in many instances protect employers whose practices conform to EEOC guidelines, or affirmative action programs adopted pursuant to the Executive Order covering government contractors. Title VII provides protection against damages liability on the part of firms that in good faith have conformed to and relied on any written interpretation by the EEOC. ${ }^{104}$ And under the EEOC's guidelines ${ }^{195}$ issued shortly before the Supreme Court's decision in Weber-and embodying the position urged by the government in that case-an employer is insulated against damages liability if he engages in reasonable affirmative action in order to redress statistical disparities or to carry out an affirmative action plan pursuant to the Executive Order. Given the looseness of the Court's justifications for upholding the Kaiser program, reliance on almost any official guideline sanctioning such discrimination would appear to be reasonable and in good faith.

${ }^{193}$ Another source of uncertainty arises from a preemption question-whether Weber's authorization of certain "voluntary" preferences preempts more restrictive state law. Title VII by its terms appears to be nonpreemptive in this context, Civil Rights Act of 1964, § 708, 42 U.S.C. $\$ 2000$ e-7 (1976) (Title VII shall not eliminate liability imposed by any present or future state law, except when such law would "require or permit . . . any act which would be . . . unlawful" under Title VII), and seems to preserve state jurisdiction to strike down preferential programs of the kind upheld in Weber, see also Lige v. Town of Montclair, 72 N.J. 5, 17-18, 22, 367 A.2d 833, 839-40, 842 (1976). Under this view, the states would be free to frustrate the congressional purpose, stressed by the Court in Weber, of avoiding overregulation of employers and unions. The Court could avoid that anomalous result only by disregarding what appears to be the clear antipreemption language in Title VII.

194 See Civil Rights Act of 1964, § 713(b), 42 U.S.C. $\S 2000$ e-12(b) (1976).

195 Affirmative Action Appropriate Under Title VII of the Civil Rights Act of 1964, as Amended, 29 C.F.R. § 1608 (1979). The guidelines sought to confer immunity for "reverse discrimination" more expansive than the immunity that could now be derived from the Supreme Court's decision in Weber, narrowly read. Whatever one's view of either the EEOC's promulgation of the guidelines while Weber was sub judice or the EEOC's failure, following the Weber decision, to qualify the guidelines in the light of that decision, an employer's good-faith reliance on the guidelines would as of now appear to meet the good-faith requirement of section 713(b), see text and note at note 194 supra. 
As a consequence, the Court's apparent effort in Weber to limit the scope of permissible preferences may well be frustrated by the Court's simultaneous failure to formulate an approach that transcends the instant case. The uncertainties generated by Weber may encourage the OFCC to step up pressure for "results"; those pressures, coupled with the prospect of immunity against damages for adopting preferential programs, may in turn propel employers to multiply such programs for various groups. The irony, noticed by Justice Rehnquist, ${ }^{198}$ of labeling such formal or de facto quotas "voluntary" will be more marked if Weber is followed by an increase in the vigor or candor with which the procurement club is wielded as a means of "quotification."

\section{Conclusion}

Weber has rebuffed a challenge to preferential hiring designed to benefit black workers. But the foregoing questions reflect Weber's accordion-like potential: it may be severely limited or broadened, without doing violence to its plastic language. For the present, the Court's work in Weber has the value of underscoring the profound immorality of the older racism. But the Court legitimated a new form of racism that places disproportionately heavy burdens on the Brian Webers of the world and that repudiates an ideal of equal opportunity that has deserved and commanded broad support. In reworking both the moralities and the language of Title VII, the Court did not address the deeper issues of values and legal process that met in the Weber case. The net result is an opinion that, with respect, is a profound disappointment, whether tested by its depth, its clarity, its candor, or its power to convince. $^{198}$

${ }^{108} 443$ U.S. at 246 (Rehnquist, J., dissenting).

197 The elasticity of the "voluntariness" concept is shown by the holding that compliance with the recent wage and price guidelines, even though they are theoretically enforceable by debarment, is "voluntary" because there is no "right" to hold a government contract. See AFL-CIO v. Kahn, [1979] 4 LAB. REL. REP. (BNA) (24 Wage and Hour Cas.) 162 (D.C. Cir. June 22, 1979) (en banc), cert. denied, 443 U.S. 915 (1979). Judge MacKinnon dissented, arguing in part that Congress did not intend to grant the President such power. Id. at 171. Judge Robb also dissented, stating in part that "[n]o amount of sophisticated or metaphysical argument can convince me that compliance under threat of such massive economic sanctions is voluntary." Id. at 186 (footnote omitted).

108 After remand, Judge Gee, who had previously spoken for the court of appeals in Weber, filed an extraordinary statement expressing his "personal conviction that the decision of the Supreme Court . . . is profoundly wrong." Weber v. Kaiser Aluminum \& Chem. Corp., 611 F.2d 132, 133 (5th Cir. 1980). Judge Wisdom, although describing that decision as 

only Justice Blackmun had embraced. Id. (Wisdom, J., specially concurring). 